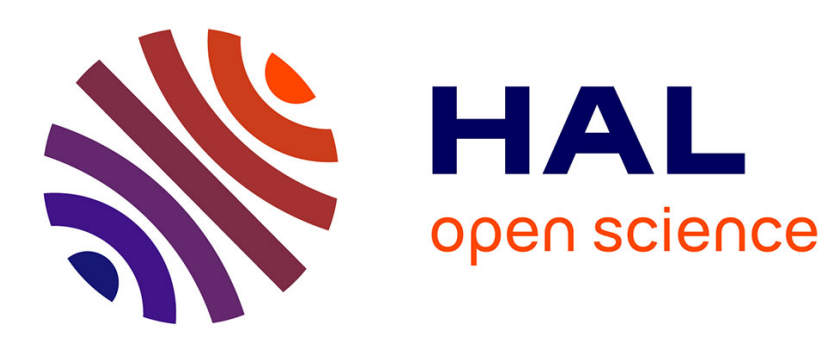

\title{
Border Effects in the Enlarged EU Area. Evidence from Imports to Accession Countries
}

\author{
Anna Maria Pinna, Manchin Miriam
}

\section{To cite this version:}

Anna Maria Pinna, Manchin Miriam. Border Effects in the Enlarged EU Area. Evidence from Imports to Accession Countries. Applied Economics, 2009, 41 (14), pp.1835-1854. 10.1080/00036840601044974 . hal-00581996

\section{HAL Id: hal-00581996 https://hal.science/hal-00581996}

Submitted on 1 Apr 2011

HAL is a multi-disciplinary open access archive for the deposit and dissemination of scientific research documents, whether they are published or not. The documents may come from teaching and research institutions in France or abroad, or from public or private research centers.
L'archive ouverte pluridisciplinaire HAL, est destinée au dépôt et à la diffusion de documents scientifiques de niveau recherche, publiés ou non, émanant des établissements d'enseignement et de recherche français ou étrangers, des laboratoires publics ou privés. 


\section{Border Effects in the Enlarged EU Area. Evidence from Imports to Accession Countries}

\begin{tabular}{|c|c|}
\hline Journal: & Applied Economics \\
\hline Manuscript ID: & APE-05-0534.R1 \\
\hline Journal Selection: & Applied Economics \\
\hline JEL Code: & $\begin{array}{l}\text { F13 - Commercial Policy|Protection|Promotion|Trade Negotiations < } \\
\text { F1 - Trade < F - International Economics, F15 - Economic } \\
\text { Integration < F1 - Trade < F - International Economics, F14 - } \\
\text { Country and Industry Studies of Trade < F1 - Trade < F - } \\
\text { International Economics }\end{array}$ \\
\hline Keywords: & $\begin{array}{l}\text { F13 - Commercial Policy|Protection|Promotion|Trade Negotiations < } \\
\text { F1 - Trade < F - International Economics, F15 - Economic } \\
\text { Integration }<\text { F1 - Trade < F - International Economics, F14 - } \\
\text { Country and Industry Studies of Trade < F1 - Trade < F - } \\
\text { International Economics }\end{array}$ \\
\hline
\end{tabular}

\section{S ScholarONE" \\ Manuscript Central}




\title{
Border Effects in the Enlarged EU Area.
}

\section{Evidence from Imports to Accession Countries ${ }^{1}$}

\author{
Miriam Manchin \\ Tinbergen Institute, Rotterdam \\ Anna Maria Pinna \\ Department of Economics, CRENoS (University of Cagliari) and CEPS \\ Contact addresses: \\ ampinna@unica.it; manchin@few.eur.nl
}

This draft: July 2005

\begin{abstract}
By looking at imports of Eastern European countries we provide novel insights on the importance and magnitude of border effects and on how they are linked with technical barriers to trade. The use of a panel allows us to assess if border effects changed over the transition period. All CEECs considered trade with themselves more than with other countries and the home bias found is higher than in the case of EU countries. We grouped products into three categories; old approach, new approach (including mutual recognition), and mixed. Our results show border effects are the largest for old approach products, where we expect to have the most important technical barriers. The 'new approach' category has the smallest border effects, while the 'mixed approach' products are in between. For new approach products and mixed approach products the magnitude of border effects was declining at the end of the 90 s.
\end{abstract}

JEL Classification: F13, F15

The authors acknowledge comments and suggestions from Paul Brenton, Keith Head, Thierry Mayer, Sandra Poncet, Eric Strobl and Daniel Weiserbs. We also thank participants at a seminar in Louvain-la-Neuve and at the ETSG conference in Madrid. Errors have to be attributed only to us. 


\title{
Border Effects in the Enlarged EU Area.
}

\section{Evidence from Imports to Accession Countries ${ }^{2}$}

This draft: July 2005

\begin{abstract}
By looking at imports of Eastern European countries we provide novel insights on the importance and magnitude of border effects and on how they are linked with technical barriers to trade. The use of a panel allows us to assess if border effects changed over the transition period. All CEECs considered trade with themselves more than with other countries and the home bias found is higher than in the case of EU countries. We grouped products into three categories; old approach, new approach (including mutual recognition), and mixed. Our results show border effects are the largest for old approach products, where we expect to have the most important technical barriers. The 'new approach' category has the smallest border effects, while the 'mixed approach' products are in between. For new approach products and mixed approach products the magnitude of border effects was declining at the end of the 90 s.
\end{abstract}

JEL Classification: F13, F14, F15 


\subsection{Introduction}

This paper looks at barriers to trade and the level of integration between the EU and Central Eastern European Countries (CEECs). More specifically we analyse the issue of border effects in the enlarged EU. The objective is to examine whether technical barriers to trade influences border effects and to estimate the magnitude of the border effects in CEECs trade with the EU.

Evidence of border effects in the exchanges of Central and Eastern European Countries is still an undeveloped issue in the literature. Only Sousa and Disdier (2002) have assessed the effect of legal framework on bilateral trade flows of Hungary, Romania and Slovenia with EU and CEFTA countries using the 'border effects' approach. Referring to the period 1995-1998 they find more significant border effects towards CEFTA countries than towards EU countries. In this chapter we consider accession countries of different size and other characteristics, i.e. Hungary, Poland, Czech Republic, Romania, Latvia and Cyprus, and measure the extent to which internal trade exceeds international trade in a set up where controls for other economic determinants of commerce are considered.

Until now the issue of border effects has been investigated along different dimensions. First, evidence in the literature concentrated on borders between countries (McCallum, 1995; Wei, 1996; Nitch, 2000; Head and Mayer, 2000). These papers show surprisingly large and time enduring border effects comparing intra-national and international exchanges of Canada, US and Europe. McCallum (1995) found that trade flows between Canadian provinces were about 22 times as large as their trade with US states of the same size and distances. Several studies arrived at similar results looking at trade in North America, OECD and Europe ${ }^{3}$.

Starting from Wolf $(1997,2000)$ border effects have been investigated also at the intra-national level. Referring to the US, Wolf $(1997,2000)$ finds intra-state trade excessive relative to inter-state trade, such evidence suggesting a degree of market fragmentation also at the national level. Similar intra-national evidence for an EU country has been recently provided by Combes, Lafourcade and Mayer (2003); administrative borders in France have been shown to have a negative impact on trade.

\footnotetext{
${ }^{3}$ See, among others, Anderson (2001), Anderson and van Wincoop (2003), Chen (2004), Evans (2003, 2001), Head and Mayer (2000), Helliwell (1995, 1997, 1998, 2000), Helliwell and Verdier (2000), Hillberry (1999,2001), Hillberry and Hummels (2002), Nitsch (2000), Wei (1996), and Wolf (1997, 2000).
} 
Head and Mayer (2000) estimated the size of border effects in the European Union by using the gravity approach on sectoral data. The paper finds no correlation between non-tariff barriers and the border effect, and the authors conclude that the cause of the border effects lies in the bias of consumer preferences towards domestically produced goods. Differently Brenton and Vancauteren (2001) find that for sectors grouped by the approach the EU adopted to removing technical barriers (old approach, mutual recognition, new approach and sectors where technical barriers are not important) border effects are significant for all groups of sectors except for those subject to mutual recognition. If border effects are high for sectors where technical barriers are not important other factors than policy-induced barriers play an important role in creating them.

More recently Chen (2004) examines the border effects for a set of European countries for the year 1996 finding important differences in border effects between industries. Factors taken into account which contribute to explain border effects include the transportability of products, 'multilateral trade resistance ${ }^{4}$, information costs ${ }^{5}$, spatial clustering, and technical and non-tariff barriers to trade. Technical barriers to trade and product-specific information costs increase border effects, while on the other hand non-tariff barriers are not significant.

This paper does not aim to address directly the issue of defining the elements that contribute to create a border but instead looks at the impact of technical barriers on border effects. With the exception of Chen (2004) other empirical works have not been able to confirm that technical barriers to trade increase border effects. Furthermore Chen (2004) covered only one year, thus the analysis was not able to evaluate if the importance of technical barriers to trade for border effects has changed over time. By looking at Eastern European countries our estimates on border effects can provide novel insights on the importance and magnitude of border effects and the role of technical barriers to trade. We evaluate whether market fragmentation and technical barriers to trade in the CEECs area, particularly when referring to imports from EU countries, is more relevant than existing evidence for trade within the EU 15. Furthermore, by using a panel data we can assess if border effects changed over time.

As in Brenton and Vancauteren (2001) we consider this issue in the context of the impact of regulatory policies on international trade flows. We look at the extent of border effects for sectors

\footnotetext{
${ }^{4}$ Anderson and Wincoop (2003) argue that bilateral trade is not only influenced by bilateral trade barriers but also by the average trade barriers that both partners face with all their trading partners, which they call 'multilateral trade resistance'. Chen (2004) instead of constructing the multilateral resistance terms included country fixed-effects .

${ }^{5}$ Information costs captured partly by average firm size calculated for each sector and by using three dummies for industries according to whether search costs are assumed to be either lower or higher.
} 
grouped according to the approach adopted by the EU to remove technical barriers to intra-EU trade. The gravity model is applied to data that identifies separately sectors subject to the different approaches to the removal of technical barriers in the EU. Furthermore in order to avoid the possibility of inflated border effects due to the mismeasurement of distances, information at the regional level both for CEECs and EU countries has been used in order to construct a weighted measure of distance both for between-countries and internal distances.

The paper proceeds as follows. The next section reviews the data used for the analysis. We then discuss technical barriers to trade (section 3) and the issue of distance measurement (section 4). Section 5 discusses the basic model and the econometric issues raised by estimating gravity equations. We then discuss the results of the basic model in section 6. In section 7 sectoral and over time border effects are examined. Conclusions follow in the final section.

\subsection{The Data}

Our data set consists of trade flows for the period 1992-1998 between a sample of accession countries (Cyprus, Bulgaria, Hungary, Latvia, and Poland) and EU countries and other accession countries. ${ }^{6}$ Both trade and production data originate from the World Bank Trade and Production Database and the data is in International Standard Industrial Classification (ISIC) Rev. 2. The World Bank database is constructed from the COMTRADE database for trade data and the production data originating from UNIDO and OECD sources. Trade data was originally in SITC rev. 2 classification, but it was then transformed to ISIC rev.2 by the World Bank. Both production and trade data are in thousands of US dollars and cover 28 manufacturing sectors. Trade and production data was transformed into NACE 70 classification in order to identify products for which new approach and mutual recognition, old approach, or mixed approach applies. Moreover, trade data was deflated by a GDP deflator which was obtained from the World Development Indicators database.

In order to identify these three different categories we use the data from the detailed study undertaken for the Commission's review of the impact of the Single Market in the EU $\left(1998^{7}\right)$. This study provides information, at the 3-digit level of the NACE classification, of the dominant approach used by the Commission for the removal of technical barriers in the EU.

\footnotetext{
${ }^{6}$ EU 15 Member States, with Belgium and Luxembourg aggregated as one country, while the number of accession countries varies by reporting countries and years depending on the data availability.

${ }^{7}$ European Commission (1998), 'Technical Barriers to Trade', Volume 1 of Subseries III Dismantling of Barriers Of the Single Market Review, Office for Official Publication, Luxembourg
} 
To measure internal trade we use the approach proposed by Wei (1996) who showed how the gravity equation could be used to estimate border effects when data on trade flows by sub-national units are not available. The idea is that internal trade can be represented by the value of production minus exports to other countries. The coefficient of a dummy taking the value of 1 for the observations related to internal trade can then be interpreted as the border effect.

GDP data is obtained from the World Development Indicators database. Constant GDP values were used where the data were in thousands of US dollars. Distance data was obtained from the New Cronos database of Eurostat.

\subsection{Technical Barriers to Trade and the EU Instruments to their Removal}

Technical barriers to trade result from differences in product requirements and in the approval and control procedures (testing, certification, etc.) for evaluating compliance with such requirements between countries. These differences in national technical regulations and standards can have important adverse effects on the bilateral trade flows, by increasing costs, distorting production processes and discouraging business co-operation. On the other hand, the full harmonisation of all product-related technical regulations can result in slow and ineffective procedures. In the EU before the ' 80 s harmonisation of all product categories was achieved by the so-called 'old approach', where harmonization was very technical requiring in-depth consultations. Moreover, the adoption of the old approach directives required unanimity in the Council of Ministers. These long delays resulted in ineffectiveness since national regulations were produced at a much faster rate than the production of harmonised EU directives (Pelkmans, 1987). Nevertheless, a number of old approach directives still remain in force covering a wide range of product groups such as pharmaceuticals, foodstuffs and motor vehicles.

In order to minimise technical barriers to trade in the EU and to reduce the costly procedure of product by product, or component by component, harmonisation of technical regulations, the EU initiated a 'new approach' in the 1980s which combines both harmonisation of different regulations and mutual recognition. Harmonization under the new approach is required when for similar products the different national regulations differ significantly and Mutual Recognition cannot be achieved. One of the key elements which allow harmonization under the new approach to be more effective than the old approach is that the directives can be adopted by majority voting. Furthermore, only essential requirements are indicated for the producers or service providers, thus giving greater flexibility. 
The principle of mutual recognition was applied in cases where the harmonisation of regulations and standards is not considered essential from either a health/safety or an industrial point of view. It means that, in any sectors which have not been subject to harmonisation measures, or which are covered by minimal or optional harmonisation measures, every country is obliged to accept into its territory products which are legally produced and marketed in another country. In other words, a producer or service provider who has fulfilled the requirements of his country of origin can sell his products or provide his services in the partner country. However, it often requires accreditation of testing and certification of bodies, and a mutual recognition arrangement between bodies, because countries often regulate risks in slightly different ways for the same product (Brenton, Sheehy, Vancauteren, 2001).

As part of the pre-accession strategy a special type of mutual recognition agreement (Protocols to the Europe Agreement on Conformity assessment and Acceptance of industrial products (PECAs)) was recently concluded with several accession countries. According to these agreements mutual recognition operates on the basis of the acquis communautaire. PECAs treat all mandatory approval procedures in the sectors that they cover. They are made up of a framework establishing general principles and procedures for the mutual recognition of results of conformity assessment and mutual acceptance of industrial products. The EU expects the applicant countries to apply the transposition of harmonised European product legislation at the latest by the date of accession. The application of the complex EU legislation on goods requires reform of both product legislation and administrative traditions based on national preferences and controls. Thus it requires a transitional period for the accession countries to be able to transpose the legislation. Several countries had applied the acquis communautaire in the field by 1999, while some other countries are still working on the transposition of EU regulations. One should note though that our data covers the period 1992-1998 when mutual recognition agreements were not yet implemented we expect that most of the countries have started to align their approach to products already before the mutual recognition agreements.

To measure the importance of technical barriers to trade we group the products into three broad categories according to the approach applied by the EU. We follow the sectoral information provided by the study undertaken for the European Commission (European Commission, 1998) which identifies the industries affected by technical barriers to trade.

The first group includes products for which harmonization under the old approach applies. The second group consists of products for which the new approach applies either in the form of Mutual 
Recognition Principle or by setting the minimum requirements ${ }^{8}$. The final group, 'mixed approach' group includes products where both old and new approach applies to the products ${ }^{9}$. The grouping of the products to these three categories provides a proxy for the different level of technical barriers applying to the products not only for trade within the EU but also with other regions. Old approach products include products with important health and safety requirements, such as pharmaceuticals, foodstuffs etc, which products are expected to meet relatively more severe technical regulations in CEECs as well than products for which safety and health concerns are not so important, such as products under new approach in the EU.

By applying this specification for measuring the importance of technical barriers to trade in different product categories we follow a similar classification used by Brenton and Vancauteren (2001) which allows us to compare our results on Eastern European countries to those obtained by Brenton and Vancauteren (2001) for EU Member States. Chen (2004) also uses a very similar method by creating an index variable which ranges from one to five depending on the importance of technical barriers to trade based on the same study prepared by the European Commission (1998).

Figure 1 shows the importance of different product categories in imports of Bulgaria, Cyprus, Hungary, Poland, and Latvia from the EU and in 'home trade' (defined as production minus exports). For all the countries intra-national trade in old approach products was significantly much higher than between country trade in this product category. Furthermore, new approach products are less important in the imports of Hungary and Bulgaria, then in the imports of the other countries.

[Figure 1 here]

\subsection{The Issue of Distance Measurement}

An issue linked to understanding the nature of border effect is how to provide estimates robust to controls for other elements giving an economic meaning to borders between states. Exchanges between economic actors are normally found to cost more if they cross any kind of administrative borders. Accounting for the difference in the costs involved in moving products within a country or between countries is therefore a crucial point.

\footnotetext{
${ }^{8}$ Due to the conversion from ISIC to NACE70 there were few ISIC product categories for which according to NACE codes new approach and also no specific approach applied. These were also grouped in the 'new approach' category, the group which consists of products with least technical barriers, since when no approach applies for a product implies that there are no important technical barriers.

${ }^{9}$ Products under the mixed approach could not be separated into the old and new approach, partly due to the conversion from ISIC to NACE70 and partly because for certain products both approaches apply. Details on the industries covered by our data are provided in Annex II.
} 
The gravity approach to modelling exchanges between economic actors contains the idea that space involves costs, other things being equal. Such costs are captured by geographical (distance) variables. This requires the measurement of the distance between a country and its trade partners and, importantly, the measurement of internal distances ${ }^{10}$. The accuracy of such measures has been shown to be crucial in finding border effects which are not illusory (Head and Mayer, 2002). If internal distances are overestimated with respect to international distances border effects will be inflated, since the 'true' smaller distance would account for the 'excess' in within country exchanges. Measuring internal and international distances so as to minimise any source of bias therefore becomes a fundamental step.

Since the estimation of border effects depends first of all on the relative magnitudes of external and internal distances, it is very important to obtain measures of internal distances that preserve the true ratio between intra- and international distances. Thus we use the same method to calculate both internal and between country distances. International and intra-national distances are computed from the weighted averages of the geographic distances between the major cities of each region using regional GDP weights, allowing to emphasize the regions which should be more involved in trade. This methodology of distance measurement was used by Head and Mayer (2000) and Chen (2004). To test the robustness of distance measurement Chen (2004) used two other measure of distance used in the literature; the first method takes a quarter of the distance to the economic centre of the nearest trading partner, and the second uses the radius of a circle (whose area is the area of the country). Comparing the results on the magnitude of the border effects using the three different measures of distance Chen (2004) concludes that using the distance measurement proposed by Head and Mayer (2000) results in the smallest border effect coefficient, however the ranking for the magnitude of border effects for the different products remains the same.

In our empirical analysis we use two different types of distance measurement. The first measurement is similar to the distance measurement used by Chen (2004), Head and Mayer (2000). The second follows the approach proposed by Head and Mayer (2002). The authors pointed out the need for a constant elasticity of substitution aggregation of internal distances between districts, so that a measure of effective distance is obtained. ${ }^{11}$ Defining $i$ and $j$ as two states with $k$ and $l$ districts within the states respectively, whose total income (GDP) is defined by the $y$ variables, the formula that satisfies the definition of effective distance between countries $i$ and $j\left(d_{i j}\right)$ is:

\footnotetext{
${ }^{10}$ For internal distance it is meant the distance a country from itself (Head and Mayer, 2002)

${ }^{11}$ Defining state the smallest unit for which trade data are available and districts the smallest unit for which geographic information is available, effective distance between two states is defined as the solution of an equation summing trade between all the districts as a function of district-to-district distances. See Head and Mayer (2001) page.13.
} 
$d_{i j}=\left(\sum_{k \in i}\left(\frac{y_{k}}{y_{i}}\right) \sum_{l \in j}\left(\frac{y_{l}}{y_{j}}\right) d_{k l}^{\theta}\right)^{1 / \theta}$

The first sum refers to the share of each region $\mathrm{k}$ in country i's GDP and the second refers to the share of region 1 in country j's GDP. The same formula is applied when calculating internal distances $(\mathrm{i}=\mathrm{j})$. When $\theta=1$, this formula is a generalisation of the standard formula used to calculate the average distance (as in Head and Mayer, 2000, and Chen, 2004). Several gravity exercises have shown the value of $\theta$ to be around -1 . Accepting such an assumption the harmonic mean will be defined.

Along with the argument of using a measure for $\theta$ consistent with results from the gravity literature, there is a potential case for inflated border effects from using the arithmetic mean. Whenever different, the harmonic mean is less than the arithmetic mean. If the difference in the two measures is in absolute terms higher for internal distances, illusory border effects may be due simply to the use of an aggregation formula (the arithmetic mean) which overestimates more the internal distances than the international ones ${ }^{12}$ (see further details about the methodology used for distance measurement in the Appendix ).

\subsection{Empirical methodology}

To estimate border effects we use the gravity equation which is the most successful empirical model of trade volumes. We augment the standard gravity equation with some of the more recent theoretical developments related to that technique (Anderson and Wincoop, 2003, Rose and Wincoop, 2001). Although gravity models have been long criticized because it lacked theoretical foundations, it gained firm microfoundations long ago (Anderson 1979). Further theoretical refinements have been developed since in support of the gravity model (Bergstrand 1985, 1989; Deardorff 1995; Anderson and van Wincoop 2003; Eaton and Kortum 2001).

We estimate the following gravity equation:

$$
\begin{aligned}
& \ln X_{i j k t}=\alpha+\beta_{1} \ln G D P_{i t}+\beta_{2} G D P_{j t}+\beta_{3} G D P C_{i t}+\beta_{4} \ln D_{i j}+\beta_{5} A_{i j}+ \\
& +\beta_{6} E U_{i j}+\beta_{7} C E F T A+\beta_{8} F T A+\beta_{9} O A+\beta_{10} N A+\beta_{11} M A+\varepsilon_{i j t k}
\end{aligned}
$$

\footnotetext{
${ }^{12}$ In other words, it is not the difference between the two aggregation schemes that matters. It's the bias in the relative measure of distance (international versus internal) imposed by using one or the other which is crucial in raising illusory border effects.
} 
All variables in equation (2) are expressed as logarithm. $\mathrm{X}_{\mathrm{ijkt}}$ is the value of imports by country $i$ from country $j$ in year $\mathrm{t}$ and product $\mathrm{k}$. It also includes home trade when $\mathrm{j}=\mathrm{i}$ which is calculated as the difference between exports and production. $\mathrm{GDP}_{i t / j t}$ is the level of income in country $\mathrm{i} / \mathrm{j}$ in period t. $\mathrm{D}_{\mathrm{ij}}$ is the distance between the trading centres of the two regions (see further details in section 2.4).

$\mathrm{A}_{\mathrm{ij}}$ indicates adjacency between country $i$ and $j$, and takes the value of one if $i$ and $j$ have common borders and zero otherwise ${ }^{13}$.

EU, CEFTA, and FTA are dummy variables indicating if both partner and reporting countries are members of the Europe Agreements, CEFTA or other free trade agreement. In all cases we choose the date of entering into force of the agreement instead of the signing date.

The key parameters in our regression are $\beta 9, \beta_{10}$ and $\beta 11$, the coefficients of the home dummy variables. OA, NA, and MA are the dummy variables for border effects in old approach, new approach and mixed approach products respectively, which are equal to one for domestic trade Xii and to zero for international trade Xij in the different product categories. A positive coefficient suggests a preference for trading within the country rather than with other countries. The antilog of the coefficients measures the size of the border effect for the different product categories.

The structure of demand, and thus the structure of imports will change as the level of income changes. One might expect that as income increases, the share of most manufacturing goods will, at some income level, start to decline (Vancauteren, 2004). In order to relax the assumption of constant own income elasticity embodied in the gravity equation which might be problematic at the disaggregated level we follow the approach proposed by Vancauteren (2004). Thus we include GDPCit in the estimated equation which relaxes the assumption of constant own income elasticity. The variable is the logarithm of current per capita income for country $\mathrm{i}$ in year $\mathrm{t}\left(c G D P_{i t} / \mathrm{POP}_{i t}\right)$ with respect to the average per capita GDP of the reporting countries in $1995\left(G D P^{0}\right)$ multiplied by the $\log$ of the GDP for the given year: $G D P C_{i t}=\ln \left(\frac{c G D P_{i t} / P O P_{i t}}{G D P^{0}}\right) * \ln G D P_{i t}$.

\footnotetext{
${ }^{13}$ Adjacency dummies in the gravity equations tend to be highly significant. This can be partly due to the fact that neighbouring countries can be expected to have an additional stimulus to trade because of similarity of tastes, an awareness of common interests, some personal and business linkages especially when the border regions are highly populated or when in the past the border was somewhere else (for example in the case of some Central and Eastern European countries. Aitken (1973) also argues that neighbouring countries are likely to experience significant additional amounts of international trade in mainly locally traded goods, especially where border regions are densely populated, as in much of Europe. Therefore we include a dummy for countries which share common borders and we expect to obtain positive coefficients.
} 
Anderson and Wincoop (2003) argue that bilateral trade flows depend on the destination and origin price levels which are related to the existence of trade barriers ("multilateral resistance"). They propose a method which consistently and efficiently estimates gravity equations by including reporting and partner country fixed effects. To avoid inflated border effects and inconsistent results we control for price effects in both of the destination and origin markets (and for other regional specificities which would be omitted) by including origin and destination fixed effects interacted with industry dummies. ${ }^{14}$

What plays a crucial role for estimating non-biased gravity parameters are proper controls for the heterogeneity in trade flows across countries and controls for business cycle effects (Mátyás, 1997, 1998, Blanchard and Mátyás 1998)). Panel data analysis allows such controls to be implemented. Business cycle effects other than those reflected by changes in the GDP can be controlled as time fixed effects, i.e., treated as time dummies and estimated. Therefore we also include time fixed effects in all estimations.

Another econometric issue arises since our dependent variable is censored around zero. Around $34 \%$ of our observations are characterised by zero values. If we would drop observations with zero values we would loose information on why no trade occurred in certain cases. We follow the approach used by Eichengreen and Irwin (1993) and transform the dependent variable to $\ln \left(1+\mathrm{X}_{\mathrm{ij}}\right)$. We estimate the model with tobit specifications to correct the OLS bias from censoring.

If nonnormality is present it can result in inconsistent estimates when tobit is used. Thus we undertook some sensitivity analysis and estimate the same model with OLS and with Powell's (1984) Censored Least Absolute Deviations (CLAD) estimator. CLAD estimator permits nonnormal, heteroscedastic and asymmetric errors. CLAD is a semiparametric approach which uses the method of least absolute deviations to obtain regression coefficient estimates by minimizing the sum of absolute residuals. It is a generalization of the sample median to the regression context just as least squares is a generalization of the sample mean to the linear model (Chay and Powell, 2001).

\subsection{Econometric Results}

\section{Least Dummy Variable Model Estimator}

Table 1 presents results from the tobit estimation. The first two equations include controls for reporting, partner country and time fixed effects. The second two equations include industry

\footnotetext{
${ }^{14}$ See Rose and Wincoop (2001), Chen (2004).
} 
specific dummies interacted with partner and reporting dummies to capture different price effects in each region for each product. All equations contain three dummy variables for the border effects of different product categories. While equation (1) and (3) use distance measures calculated with the "average" methodology, in equation (2) and (4) we use the harmonic distances. All home dummies are smaller when the latter approach is used which are in line with the results and propositions of Head and Mayer (2002). On the other hand, border effect dummies are higher when industry specific dummies are included. However, the ranking on the magnitude of the border effects between the different product categories remain the same through the four different specifications.

[Table 1 here]

The dummies capturing border effects are significant and high for all three categories. Across all equations old approach products display the highest border effects. The coefficient for new approach products is the smallest, while for mixed approach products the border effect is in between the two other categories' coefficient (which is in line what one would expect since the mixed approach contains products for which both old and new approach apply). We tested if the coefficients between the different categories are significantly different and found that for equation (1) and (2) all the coefficients are significantly different from each other. On the other hand, for equation (3) and (4) the coefficient on old approach products is significantly different from the two other product categories, however the coefficient of mixed and new approach products are not significantly different. Nevertheless, since border effects are the highest for products where technical barriers are expected to be the most important and lower for other products with less severe technical barriers to trade, these findings indicate, that technical barriers to trade increase border effects.

When measuring distance with the harmonic method we find the home coefficient to be equal to 6.06 in old approach (and 7.17 when partner and reporting specific industry dummies are included), while being 4.26 for new approach products. The coefficients are somewhat higher than those measured by Brenton and Vancauteren (2001) for EU countries, who found that in new approach products (excluding mutual recognition products) in 1994 the home coefficient was 4.81, in mutual recognition products it was 2.4 and for old approach products the coefficient was $5.32^{15}$. Although these coefficients are smaller than what we found, the reporting countries in our sample are likely to

\footnotetext{
${ }^{15}$ For the year 1997 they found slightly smaller border effects for both old and new approach products, while for mutual recognition products the border effects were not significant.
} 
have higher technical barriers on imports originating from EU countries than what would be the case for trade within the EU.

Distance takes the expected sign for all different specifications and is significant in all cases. Imports elasticity to distance ranges between 1.8 and 2.2 through the different specifications which is close to the one found by Chen (2004) who found the coefficient of distance to be around 1.7, although it is somewhat larger than the magnitude found by most other studies (for example Wei (1996) found a coefficient equal to 1.39, Head and Mayer (2000) found the coefficient to be around unity). Theory however shows that the elasticity of trade with respect to distance is given by the elasticity of substitution between products times the elasticity of trade costs with respect to distance (Anderson and van Wincoop, 2003). Therefore assessing whether the coefficient is too large or too small is not possible without knowing the values of the two factors (Chen, 2004).

Adjacency is always significant and positive implying that the reporting countries in our sample trade more with neighbouring countries than with countries with similar characteristics which are not geographical situated next to them.

The dummy which stands for the Europe Agreement is significant and positive implying that the implementation of the Europe Agreements had a positive impact on accession countries' bilateral trade flows during the period 1992-1998. These agreements helped to reduce border effects between EU partner countries and signatories of the Europe Agreements. This implies that the Europe Agreements substantially mitigated border effects for trade with partner countries, although border effects still remain to be important. The coefficient of CEFTA, the variable measuring the effects of the Central Eastern European Free Trade Agreement, is significant and takes a negative sign. This indicates that the reporting countries in our sample trade more with the EU than with other countries in the region and that the CEFTA did not deliver increased trade between its members.

\section{Sensitivity analysis}

Tobit estimates are very sensitive to the nonnormality distribution and heteroscedasticity structure of the residuals. Our diagnostic tests indicated potential problems of nonnormality, therefore we rerun the same model using OLS techniques and Censored Least Absolute Deviations (CLAD) estimator. The validity of tobit requires correct specification of the error distribution where departures from the standard assumptions, in particular normality, imposes a strong trade-off in terms of consistency (Johnston and di Nardo, 1997). On the other hand, semi-parametric procedures lessen the dependence on a particular distribution of the residuals and the requirement of no 
heteroscedasticity in their structure, due to the minimization of the sum of absolute residuals from the sample median. ${ }^{16}$ We therefore use both OLS techniques and apply the procedure presented in Chay and Powell (2001) to check the robustness of our tobit results.

We estimated the four different equations used for the tobit estimation, presented in table 1, using OLS techniques and CLAD. ${ }^{17}$ Table 2 shows the main results of this sensitivity test. The results of the OLS estimations are very similar to those found using the tobit estimator. The home bias effect is again the highest for old approach and lowest for new approach products; mixed approach products are, as expected, between the two other categories through all the different specifications. For all different specification the difference between the coefficients of the three product categories is found to be significant. The coefficient of the distance is smaller than those found using tobit. Furthermore, the coefficient of CEFTA became insignificant.

CLAD estimates in Table 2 also confirm the conclusions from the tobit and OLS analysis with respect to the importance of technical barriers to trade. The difference in border effects across products grouped according to the importance of technical barriers to trade is similar to the results found previously; border effects are the largest for old approach, while smallest for new approach products. The coefficients of border effects are, however, smaller than those found by tobit and OLS estimation. On the other hand the coefficients of distance are higher than those found by OLS and tobit methods. Similarly to tobit estimates the coefficient of the dummy variable indicating if the two trading partners are members of the CEFTA is found to be significant and negative.

[Table 2 here]

\subsection{Estimation of sectoral and over time specific border effects}

We move first to estimate industry specific border effects. Then we look at the importance of border effects over time and test if there was any significant reduction (or increase) in the magnitude of border effects for the different product categories.

\section{Estimating equation for industry specific border effects}

We estimate the following gravity equation:

\footnotetext{
${ }^{16}$ As reported in Chay and Powell (2001) for censored panel data with fixed effects, maximum likelihood estimation methods will generally be inconsistent even when the parametric form of the conditional errors distribution is correctly specified.

${ }^{17}$ Due to difficulties in achieving convergence, equations including partner and reporting country industry specific fixed effects could not be estimated with the CLAD procedure.
} 
$\ln X_{i j k t}=\alpha+\beta_{1} \ln G D P_{i t}+\beta_{2} G D P_{j t}+\beta_{3} \ln D_{i j}+\beta_{4} A_{i j}+\beta_{5} E U_{i j}+$

$+\beta_{6}$ CEFTA $+\beta_{7}$ FTA $+\beta_{8}$ Border Pr oduct $+\varepsilon_{i j t k}$

All of the variables included in equation (4) are the same as in the equation (2) with the exception of a dummy variable, BorderProduct. This dummy variable captures the border effects for each different product category included in the regression.

\section{Results of the estimation looking at industry specific border effects}

Table 3 shows the border effects for different industries. The importance of border effects is high for almost all industries, however there is a wide variation in its magnitude between different industries. Furthermore, while some differences are present between the coefficients under the two specifications, there are also some important similarities. Under both specifications, wearing apparel, footwear, textiles are among the sectors with the lowest border effects. On the other hand petroleum refineries, beverages and tobacco are products with high magnitude of border effects. Furthermore, when country specific dummies are interacted with industry specific dummies, large border effects occur in coal, wood, and pottery products.

These results are in line with other empirical work examining industry specific border effects which also found that food products tend to have the highest border effect. Sousa and Disdier (2002) found the a border effect of 378 (exponential of the coefficient) for food products in the trade flows of CEFTA countries, the second highest border effect was found for printing and publishing with a magnitude of 221, while the lowest was found for textiles with a magnitude of 4 . Head and Mayer (2000) also find high border effects for food products, beverages, oil refineries, and rather low coefficients for textile products.

[Table 3 here]

\section{Estimating equation for the evolution of border effects over time}

The following gravity equation is estimated to measure changes in border effects over time:

$$
\begin{gathered}
\ln X_{i j k t}=\alpha+\beta_{1} \ln G D P_{i t}+\beta_{2} G D P_{j t}+\beta_{3} \ln D_{i j}+\beta_{4} A_{i j}+\beta_{5} E U_{i j}+ \\
\beta_{6} \text { CEFTA }+\beta_{7} F T A+\beta_{8} \text { OATime }+\beta_{9} \text { NATime }+\beta_{10} \text { MATime }+\varepsilon_{i j t k}
\end{gathered}
$$

Dummy variables are included in equation (5) for each product category interacted with year dummies. OATime refers to border effects for old approach product for each year, NATime refers to new approach, and MATime refers to mixed approach products. All other variables included in equation (5) are the same as those included in equation (2). 


\section{Results of estimation looking at border effects over time}

Table 4 presents the developments of border effects in the three different categories over time. We tested if there is a significant change in the importance of border effects for the different product categories during the period. We found that for all four specifications the null hypothesis that the coefficients of old approach border effects for the different years are equal cannot be rejected. However, for new approach products and mixed approach products we find that the coefficients are significantly different over the sample. Border effects in these two categories increased until 1995, while after 1995 there was a small decline in the magnitude of border effects. Furthermore, border effects were the highest for old approach products and the lowest for new approach products reinforcing our findings that higher border effects are present for products with higher technical barriers to trade.

[Table 4 here]

\section{Sensitivity analysis}

In order to check the robustness of the results obtained by using tobit estimation techniques for product specific and over time border effects we rerun the regressions using OLS and CLAD. Table 5 presents the border effects for different industries. Similarly to the results of the tobit regressions, beverages, food products, petroleum refineries, iron have high border effects. For miscellaneous petroleum and coal products there is an important difference between CLAD estimation and OLS (and also tobit) estimation results. The results of the CLAD estimations indicate a rather low magnitude of border effects, while other estimation techniques resulted in very high border effects. The results of tobit and OLS estimations are more reliable for this product than the CLAD results, since the standard error of this coefficient is rather high using the CLAD estimator (the standard error for this variable is 1.74 while for most of other variables it is below 0.5 ).

[Table 5 here]

OLS and CLAD estimation results for the evolution of border effects over time are presented in table 6 . We tested if the coefficients within the three product categories significantly differ over time. We found both for OLS and CLAD estimates, similarly to the tobit results, that for all different specifications the border effect is not significantly different across the different years for the old approach product. On the other hand, for new approach products and mixed approach products coefficients are significantly different over the sample. The magnitude of border effects in these product categories was declining towards the second half of the period. Furthermore, for each 
year border effects were the highest for old approach products and the lowest for new approach products reinforcing our findings that higher border effects are present for products with higher technical barriers to trade. These results are similar to those found with tobit estimations and indicate that as trade integration increased between the reporting countries and EU countries border effects declined in sectors where technical regulations are less restrictive. This might occurred partly because harmonisation, standards, testing and conformity assessment have been gradually aligned in these countries towards those of the EU.

\subsection{Conclusions}

In this chapter we have looked at the issue of border effects by investigating imports of 5 accession countries differing in size and other characteristics (Hungary, Poland, Romania, Latvia and Cyprus). The chapter examined whether border effects are related to technical barriers to trade. We grouped products into different categories, according to the approach applied by the EU to remove technical barriers to trade which provided us with a proxy for the magnitude of technical barriers by products. To avoid inflated border effects a weighted measure of distance was used both for cross-countries and internal distances.

All accession countries included in our estimation trade with themselves more than with other countries in manufacturing products, and the home bias is higher than in the case of EU countries. We grouped products into three categories; old approach, new approach (including mutual recognition, new approach), and mixed approach (which includes products where old approach and another approach is applicable). Our results suggest that the border effects are the largest for old approach products, where we expect to have the most important technical barriers due to complicated harmonization procedures. The 'new approach' category has the smallest border effects, while the 'mixed approach' products are in between the two previous categories. Border effects are somewhat mitigated for EU partner countries, but not for other accession countries. This might be also the result of the foreign direct investment by EU firms in accession countries which was significant during this period in sectors where technical barriers to trade were important. Much of this investment probably led to production consistent with EU standards (Brenton and Vancauteren, 2001).

The magnitude of the estimated border effects seems to be too large to be consistent only with the presence of trade barriers. In this chapter we did not aim to explain fully what causes this high estimate for border effects, rather we tried to see whether we could observe some difference in the 
importance of border effects in trade in products with different magnitude of technical barriers. Thus what we could conclude from our results is that there are larger and more persistent border effects for sectors where technical regulations constitute major barriers to trade. However, border effects, although to a lesser extent, are also significant for products where technical regulations are less cumbersome. Interestingly this result is different from findings of Brenton and Vancauteren (2001), who found higher levels of border effects for sectors where technical regulations did not constitute major barriers to trade. These different results might indicate that in the EU's imports to the CEECs technical barriers matter more than in the intra-EU trade, where there are other, more important factors contributing to the border effects. Furthermore, the presence of border effects in sectors where technical regulations are less important can also be explained by other factors, such as rules of origin, spatial distribution of production, the presence of social and business networks, consumer or firm preferences and for our estimation also by tariffs.

Although tariffs were gradually dismantled during the period, we did not find a significant reduction of border effects over time for the old approach product. On the other hand, for new approach products and mixed approach products the magnitude of border effects was declining towards the second half of the period. Furthermore, for each year border effects were the highest for old approach products and the lowest for new approach products reinforcing our findings that higher border effects are present for products with higher technical barriers to trade.

Our results suggest that the estimated level of border effects is partly due to policy-related constraints, thus there is an important role for policy makers to remove these barriers. The level of trade of accession countries is substantially lower than what would arise in the absence of border effects, which is much more pronounced in trade with other accession countries than in the trade of accession countries with the EU. Certainly the border effects are present not only due to policy related constraint, but the larger border effects for products with higher technical barriers to trade suggests that an important part of the border effects in the case of the accession countries could be eliminated by removal of such barriers. 


\section{References}

Aitken, N. D. (1973), The Effect of EEC and EFT on European Trade: A Temporal Cross-Section Analysis, American Economic Review 63, pp. 881-92.

Anderson, J. E., (1979), A Theoretical Foundation for the Gravity Equation, American Economic Review 69 (1), pp. 106-16.

Anderson, J. E., (2001) Borders, Trade and Welfare, NBER Working Paper Series No. 8515

Anderson J.E. and E. van Wincoop, (2003), Gravity With Gravitas: A Solution to the Border Puzzle, American Economic Review 93 (1), pp. 170-192

Bergstrand, J. H, (1985), The Gravity Equation in International Trade: Some Microeconomic Foundations and Empirical Evidence, Review of Economics and Statistics 67 (3), pp. 474-81.

Bergstrand, J. H., (1989), The Generalized Gravity Equation, Monopolistic Competition, and the Factor-Proportions Theory in International Trade, Review of Economics and Statistics 71 (1), pp. 143-53.

Blanchard, P. and L. Mátyás, (1998), Misspecified Heterogeneity in Panel Data Models, Statistical Papers, 39, 1-27

Brenton, P, Sheehy, J and Vancauteren, M (2001), Technical Barriers to Trade in the EU : Data, Trends and Implications for Accession Countries, Journal of Common Market Studies, 39, pp. 241260

Brenton, P and Vancauteren, M (2001), The Extent of Economic Integration in Europe: Border Effects, Technical Barriers to Trade and Home Bias in Consumption, CEPS Working Document No. 171

Chay, Y. K. and Powell, J. L. (2001), Semiparametric Censored Regression Models, Journal of Economic Perspectives, 15 (4)., pp.29-42

Chen, N, (2004), Intra-National Versus International Trade in the European Union: Why Do National Borders Matter?, Journal of International Economics 63, pp.93-118

Combes, P., Lafourcade, M. and Mayer, T. (2003), Can Business and Social Networks Explain the Border Effect Puzzle?, CEPR Discussion Paper No. 3750

Deardorff, A. (1995), Determinants of bilateral trade: does gravity work in a neoclassical world?, Working Paper 5377, National Bureau of Economic Research, Washington DC

Eaton, J. and Kortum, S., (2001), Technology, Geography and Trade, Econometrica, 70(5): pp.1741-79

Eichengreen, B., Irwin, D.A., (1993), Trade blocs, currency blocs and the disintegration of world trade in the 1930s, Centre for Economic Policy Research Discussion Paper 837.

European Commision (1998), 'Technical Barriers to Trade', Volume 1 of Subseries III Dismantling of Barriers of the Single Market Review, Office for Official Publication, Luxembourg

Evans C.L., (2001), Border Effects and the Availability of Domestic Products Abroad, Federal Reserve Bank of New York.

Evans C.L., (2003), The Economic Significance of National Border Effects, American Economic Review 93 (4), pp. $1291-1312$

Head K. and T. Mayer, (2000), Non-Europe: The Magnitude and Causes of Market Fragmentation in the EU, Weltwirtschaftliches Archiv 136(2), 285-314.

Head K. and T. Mayer, (2002), Illusory Border Effects: Distance Mismeasurement Inflates Estimates of Home Bias in Trade, CEPII Working Paper No. 2002-01

Helliwell J.F., (1995), Do National Borders Matter for Quebecs Trade?, NBER Working Paper 5215. 
Helliwell J.F., (1997), National Borders, Trade and Migration, NBER Working Paper 6027.

Helliwell J.F., (1998), How Much Do National Borders Matter?, The Brookings Institution Press, Washington D.C.

Helliwell J.F., (2000), Measuring the Width of National Borders, University of British Columbia, Vancouver.

Helliwell J.F. and G. Verdier, (2000), Comparing Inter-provincial and Intra-provincial Trade Densities, University of British Columbia, Vancouver.

Hillberry R., (1999), Explaining the Border Effect.: What Can We Learn from Disaggregated Commodity Flow Data?, Indiana University Graduate Student Economics Working Paper Series 9802.

Hillberry R. and D. Hummels, (2000), Explaining Home Bias in Consumption: Production Location, Commodity Composition and Magnification, Purdue University.

Hillberry R., (2001), Aggregation Bias, Compositional Change, and the Border Effect, US International Trade Commission.

Johnston, J. and J. Di Nardo (1997): Econometric Methods, New York, McGraw-Hill

Mátyás, L. (1997), Proper Econometric Specification of the Gravity Model, The World Economy, 20, pp. 363-369.

Mátyás, L. (1997), The Gravity Model: Some Econometric Considerations, The World Economy, 21, pp. 397-401.

McCallum, J., (1995), National Borders Matter: Canada-U.S. Regional Trade Patterns, The American Economic Review, 85(3): 615-623.

Nitsch V., (2000), National Borders and International Trade: Evidence From the European Union, Canadian Journal of Economics 33(4), pp. 1091-1105.

Okubo, T. (2003), The Border Effect in the Japanese Market: A Gravity Model Analysis, RSIE Discussion Paper No. 494

Pelkmans, J. (1987), The new approach to Technical Harmonization and Standardization, Journal of Common Market Studies 25(3), pp. 249-269.

Powell, J.L, (1984), Least Absolute Deviations Estimation for the Censored Regression Model, Journal of Econometrics, 25, pp. 303-325.

Rose, A.K., van Wincoop, E., (2001), National money as a barrier to international trade: the real case for currency union, American Economic Review 91 (2), 386- 390.

Sousa, J, Disdier, A, (2002), Legal Framework as a Trade Barrier - Evidence from Transition Countries : Hungarian, Romanian and Slovene Examples, HWWA Discussion Paper 201

Vancauteren, M. (2004), Harmonization of Regulations and Trade: Empirical Evidences for the European Manufacturing Sector, PhD Thesis, Université catholique de Louvain, Louvain-la-Neuve

Wei S.-J., (1996), Intra-National Versus International Trade: How Stubborn are Nations in Global Integration?, NBER Working Paper 5531.

Wolf H.C., (1997), Patterns of Intra- and Inter-State Trade, NBER Working Paper 5939.

Wolf H.C., (2000), Intranational Home Bias in Trade, Review of Economics and Statistics 82(4), pp. $555-563$.

The authors acknowledge comments and suggestions from Paul Brenton, Keith Head, Thierry Mayer, Sandra Poncet, Eric Strobl and Daniel Weiserbs. We also thank participants at a seminar in Louvain-la-Neuve and at the ETSG conference in Madrid. Errors have to be attributed only to us. 
Figure 1 Share of different product categories grouped according to different approaches in imports from the EU and in home trade

Bulgaria

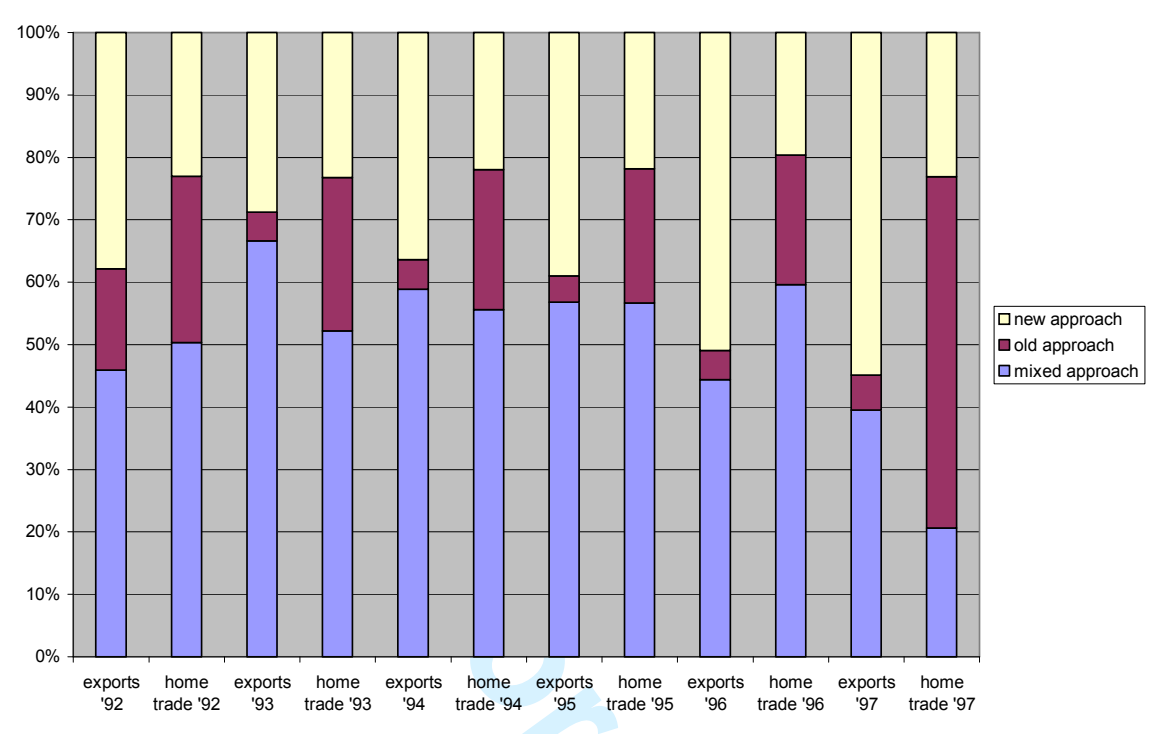

Cyprus

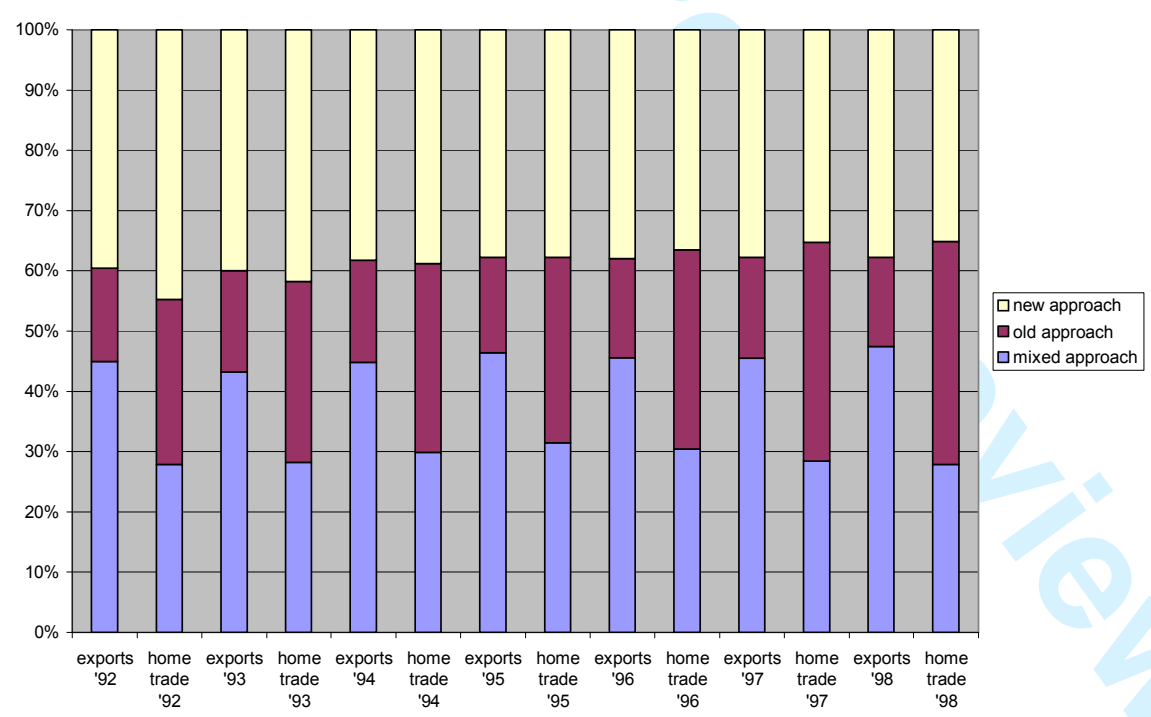



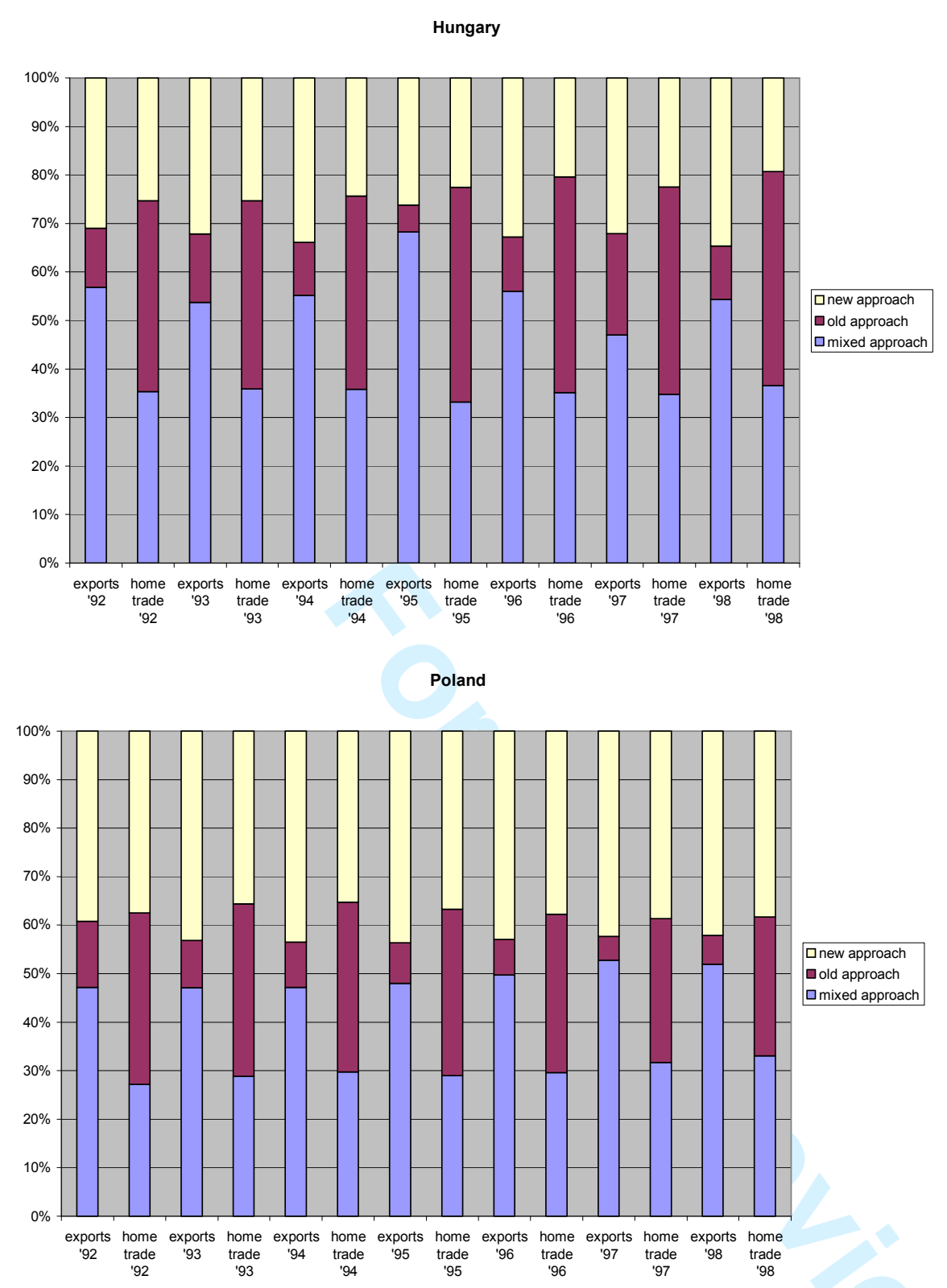


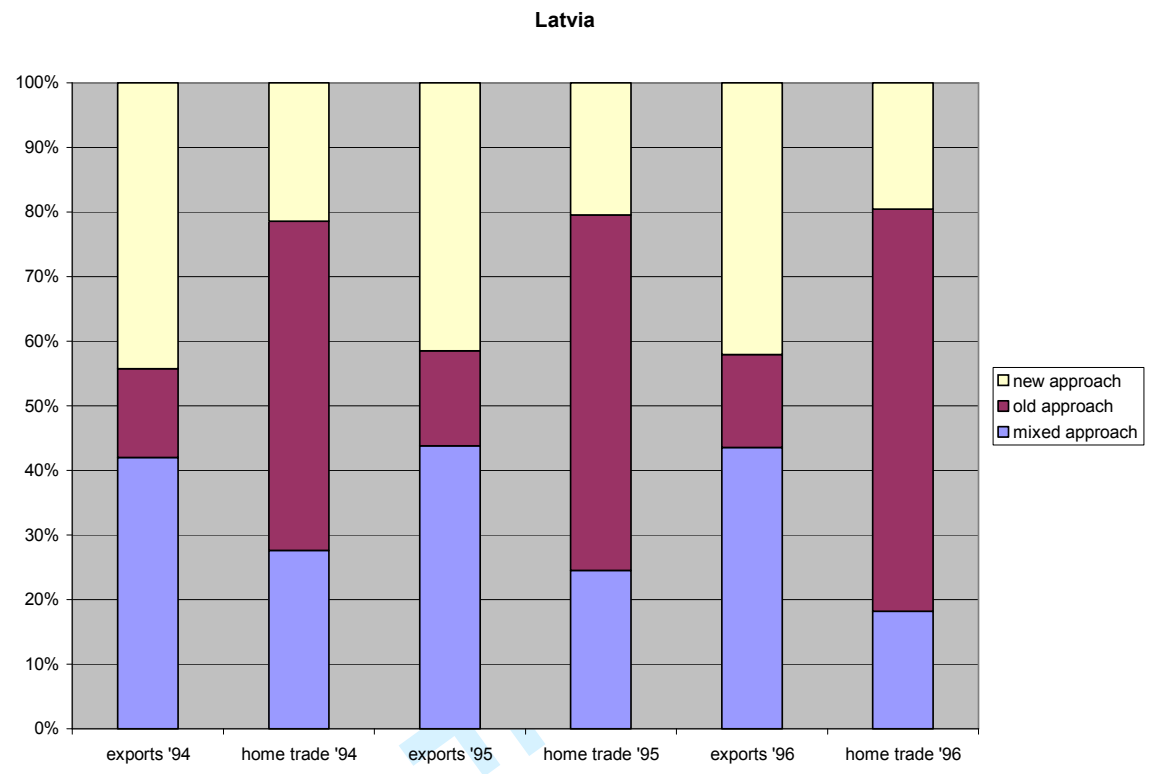


Table 1 Tobit estimations

\begin{tabular}{|c|c|c|c|c|}
\hline & $\begin{array}{l}\mathrm{Eq}(1) \\
\text { with average } \\
\text { distance } \\
\text { measurement }\end{array}$ & $\begin{array}{l}\mathrm{Eq}(2) \\
\text { with harmonic } \\
\text { distance } \\
\text { measurement }\end{array}$ & $\begin{array}{l}\mathrm{Eq}(3) \\
\text { with average } \\
\text { distance } \\
\text { measurement }\end{array}$ & $\begin{array}{l}\text { Eq (4) } \\
\text { with harmonic } \\
\text { distance } \\
\text { measurement }\end{array}$ \\
\hline GDPpartner & $\begin{array}{l}2.007 \\
(3.44)^{* * *}\end{array}$ & $\begin{array}{l}2.063 \\
(3.54)^{* * *}\end{array}$ & $\begin{array}{l}0.565 \\
(9.39)^{* * *}\end{array}$ & $\begin{array}{l}0.569 \\
(9.47)^{* * *}\end{array}$ \\
\hline GDPreporting & $\begin{array}{l}0.742 \\
(0.98)\end{array}$ & $\begin{array}{l}0.734 \\
(0.97)\end{array}$ & $\begin{array}{l}0.326 \\
(3.96)^{* * *}\end{array}$ & $\begin{array}{l}0.300 \\
(3.64)^{* * *}\end{array}$ \\
\hline GDPC & $\begin{array}{l}-0.123 \\
(4.77)^{* * *}\end{array}$ & $\begin{array}{l}-0.122 \\
(4.73)^{* * *}\end{array}$ & $\begin{array}{l}-0.020 \\
(3.33)^{* * *}\end{array}$ & $\begin{array}{l}-0.015 \\
(2.47)^{* *}\end{array}$ \\
\hline adjacency & $\begin{array}{l}0.528 \\
(4.66)^{* * *}\end{array}$ & $\begin{array}{l}0.203 \\
(1.72)^{*}\end{array}$ & $\begin{array}{l}0.822 \\
(8.74)^{* * *}\end{array}$ & $\begin{array}{l}0.558 \\
(5.68) * * *\end{array}$ \\
\hline Europe Agreement & $\begin{array}{l}0.996 \\
(10.53) * * *\end{array}$ & $\begin{array}{l}0.978 \\
(10.35)^{* * *}\end{array}$ & $\begin{array}{l}1.092 \\
(14.30)^{* * *}\end{array}$ & $\begin{array}{l}1.082 \\
(14.19) * * *\end{array}$ \\
\hline CEFTA & $\begin{array}{l}-0.283 \\
(1.95)^{*}\end{array}$ & $\begin{array}{l}-0.455 \\
(3.15)^{* * *}\end{array}$ & $\begin{array}{l}-0.218 \\
(1.81)^{*}\end{array}$ & $\begin{array}{l}-0.368 \\
(3.04)^{* * *}\end{array}$ \\
\hline FTA & $\begin{array}{l}-0.017 \\
(0.04)\end{array}$ & $\begin{array}{l}0.046 \\
(0.12)\end{array}$ & $\begin{array}{l}-0.094 \\
(0.29)\end{array}$ & $\begin{array}{l}-0.047 \\
(0.14)\end{array}$ \\
\hline Home old approach & $\begin{array}{l}7.396 \\
(15.96) * * *\end{array}$ & $\begin{array}{l}6.056 \\
(12.63)^{* * *}\end{array}$ & $\begin{array}{l}8.225 \\
(20.19)^{* * *}\end{array}$ & $\begin{array}{l}7.175 \\
(17.11)^{* * *}\end{array}$ \\
\hline Home new approach & $\begin{array}{l}5.623 \\
(19.20) * * *\end{array}$ & $\begin{array}{l}4.263 \\
(13.34)^{* * *}\end{array}$ & $\begin{array}{l}6.565 \\
(26.78) * * *\end{array}$ & $\begin{array}{l}5.498 \\
(20.70) * * *\end{array}$ \\
\hline Home mixed approach & $\begin{array}{l}6.232 \\
(20.75) * * *\end{array}$ & $\begin{array}{l}4.841 \\
(14.80) * * *\end{array}$ & $\begin{array}{l}6.792 \\
(26.88) * * *\end{array}$ & $\begin{array}{l}5.685 \\
(20.81)^{* * *}\end{array}$ \\
\hline Distance & $\begin{array}{l}-2.072 \\
(23.95) * * *\end{array}$ & $\begin{array}{l}-2.270 \\
(25.31)^{* * *}\end{array}$ & $\begin{array}{l}-1.812 \\
(25.33)^{* * *}\end{array}$ & $\begin{array}{l}-1.962 \\
(26.67)^{* * *}\end{array}$ \\
\hline Constant & $\begin{array}{l}-28.405 \\
(1.74)^{*}\end{array}$ & $\begin{array}{l}-27.911 \\
(1.71)^{*}\end{array}$ & $\begin{array}{l}3.394 \\
(1.80)^{*}\end{array}$ & $\begin{array}{l}4.831 \\
(2.55) * *\end{array}$ \\
\hline Pseudo R-squared & 0.1328 & 0.1335 & 0.2166 & 0.2173 \\
\hline Observations & 19927 & 19927 & 19927 & 19927 \\
\hline country fixed effects & yes & yes & no & no \\
\hline industry by country fixed-effects & no & no & yes & yes \\
\hline
\end{tabular}


Table 2 OLS and CLAD coefficients

\begin{tabular}{|c|c|c|c|c|}
\hline & $\begin{array}{l}\text { OLS Using harmonic } \\
\text { distance }\end{array}$ & $\begin{array}{l}\text { OLS Using harmonic } \\
\text { distance }\end{array}$ & $\begin{array}{l}\text { CLAD Using average } \\
\text { distance }\end{array}$ & $\begin{array}{l}\text { CLAD Using } \\
\text { harmonic distance }\end{array}$ \\
\hline \multirow[t]{2}{*}{ GDPpartner } & 0.996 & 0.535 & 3.014 & 2.985 \\
\hline & $(0.496)^{* *}$ & $(0.073)^{* * *}$ & $(0.9006)$ & $(0.8441)$ \\
\hline \multirow[t]{2}{*}{ GDPreporting } & 2.436 & 0.433 & 4.043 & 3.921 \\
\hline & $(0.650)^{* * *}$ & $(0.087)^{* * *}$ & $(1.25)$ & (1.364) \\
\hline \multirow[t]{2}{*}{ GDPC } & -0.133 & -0.021 & 0.149 & -0.1489 \\
\hline & $(0.023)^{* * *}$ & $(0.007)^{* * *}$ & $(0.03)$ & $(0.0306)$ \\
\hline \multirow[t]{2}{*}{ adjacency } & 0.582 & 0.830 & -0.5071 & -0.646 \\
\hline & $(0.088)^{* * *}$ & $(0.078)^{* * *}$ & $(0.187)$ & $(0.172)$ \\
\hline \multirow[t]{2}{*}{ Europe Agreement } & 0.876 & 0.901 & 0.6129 & 0.629 \\
\hline & $(0.085)^{* * *}$ & $(0.069)^{* * *}$ & $(0.123)$ & $(0.155)$ \\
\hline \multirow[t]{2}{*}{ CEFTA } & -0.038 & 0.056 & -0.585 & -0.828 \\
\hline & $(0.121)$ & $(0.093)$ & $(0.194)$ & $(0.207)$ \\
\hline \multirow[t]{2}{*}{ FTA } & -0.531 & -0.574 & 0.806 & 0.7718 \\
\hline & $(0.370)$ & $(0.295)^{*}$ & $(0.348)$ & $(0.321)$ \\
\hline \multirow[t]{2}{*}{ Home old approach } & 7.109 & 7.656 & 5.763 & 4.441 \\
\hline & $(0.291)^{* * *}$ & $(0.346)^{* * *}$ & $(0.318)$ & $(0.364)$ \\
\hline \multirow[t]{2}{*}{ Home new approach } & 5.303 & 6.142 & 4.197 & 2.871 \\
\hline & $(0.217)^{* * *}$ & $(0.202)^{* * *}$ & $(0.3982)$ & $(0.3718)$ \\
\hline \multirow[t]{2}{*}{ Home mixed approach } & 5.855 & 6.496 & 4.634 & 3.2567 \\
\hline & $(0.221)^{* * *}$ & $(0.219)^{* * *}$ & $(0.3785)$ & $(0.381)$ \\
\hline \multirow[t]{2}{*}{ Distance } & -1.674 & -1.357 & -3.727 & -3.597 \\
\hline & $(0.069)^{* * *}$ & $(0.061)^{* * *}$ & $(0.1805)$ & $(0.1747)$ \\
\hline \multirow[t]{2}{*}{ Constant } & -38.146 & -0.597 & -86.802 & -85.351 \\
\hline & $(14.054)^{* * *}$ & $(1.989)$ & $(25.941)$ & $(27.767)$ \\
\hline Observations & 19927 & 19927 & 19927 & 19927 \\
\hline R-squared & 0.53 & 0.7 & $0.34^{2}$ & $0.34^{2}$ \\
\hline country fixed effects & yes & no & yes & yes \\
\hline $\begin{array}{l}\text { industry by country fixed- } \\
\text { effects }\end{array}$ & no & yes & no & no \\
\hline
\end{tabular}


Table 3 Tobit estimation, by products

\begin{tabular}{|c|c|c|}
\hline & With country specific fixed effects & $\begin{array}{l}\text { With country-industry specific fixed } \\
\text { effects }\end{array}$ \\
\hline Food products & $\begin{array}{l}6.883 \\
(9.74)^{* * *}\end{array}$ & $\begin{array}{l}4.794 \\
(8.32)^{* * *}\end{array}$ \\
\hline Beverages & $\begin{array}{l}5.694 \\
(8.10)^{* * *}\end{array}$ & $\begin{array}{l}7.585 \\
(11.65)^{* * *}\end{array}$ \\
\hline Tobacco & $\begin{array}{l}5.001 \\
(6.82)^{* * *}\end{array}$ & $\begin{array}{l}8.853 \\
(12.33)^{* * *}\end{array}$ \\
\hline Textiles & $\begin{array}{l}4.269 \\
(6.04)^{* * *}\end{array}$ & $\begin{array}{l}2.467 \\
(3.88)^{* * *}\end{array}$ \\
\hline Wearing apparel except footwear & $\begin{array}{l}2.182 \\
(1.81)^{*}\end{array}$ & $\begin{array}{l}2.226 \\
(1.92)^{*}\end{array}$ \\
\hline Leather products & $\begin{array}{l}2.745 \\
(3.88)^{* * *}\end{array}$ & $\begin{array}{l}6.459 \\
(9.53)^{* * *}\end{array}$ \\
\hline Footwear except rubber or plastic & $\begin{array}{l}2.924 \\
(3.60)^{* * *}\end{array}$ & $\begin{array}{l}3.435 \\
(4.56)^{* * *}\end{array}$ \\
\hline Wood products except furniture & $\begin{array}{l}4.495 \\
(6.16)^{* * *}\end{array}$ & $\begin{array}{l}7.200 \\
(10.35)^{* * *}\end{array}$ \\
\hline Furniture except metal & $\begin{array}{l}4.112 \\
(5.91)^{* * *}\end{array}$ & $\begin{array}{l}6.200 \\
(9.57)^{* * *}\end{array}$ \\
\hline Paper and products & $\begin{array}{l}4.341 \\
(6.14)^{* * *}\end{array}$ & $\begin{array}{l}4.908 \\
(7.59)^{* * *}\end{array}$ \\
\hline Printing and publishing & $\begin{array}{l}4.812 \\
(6.88)^{* * *}\end{array}$ & $\begin{array}{l}5.970 \\
(9.33)^{* * *}\end{array}$ \\
\hline Industrial chemicals & $\begin{array}{l}5.546 \\
(5.25)^{* * *}\end{array}$ & $\begin{array}{l}1.911 \\
(2.10)^{* *}\end{array}$ \\
\hline Other chemicals & $\begin{array}{l}5.322 \\
(7.58)^{* * *}\end{array}$ & $\begin{array}{l}4.315 \\
(6.82)^{* * *}\end{array}$ \\
\hline Petroleum refineries & $\begin{array}{l}5.725 \\
(7.08)^{* * *}\end{array}$ & $\begin{array}{l}9.258 \\
(11.74)^{* * *}\end{array}$ \\
\hline Miscellaneous petroleum and coal products & $\begin{array}{l}5.138 \\
(4.87)^{* * *}\end{array}$ & $\begin{array}{l}11.146 \\
(10.60)^{* * *}\end{array}$ \\
\hline Rubber products & $\begin{array}{l}2.719 \\
(3.58)^{* * *}\end{array}$ & $\begin{array}{l}4.759 \\
(6.62)^{* * *}\end{array}$ \\
\hline Plastic products & $\begin{array}{l}4.641 \\
(6.64)^{* * *}\end{array}$ & $\begin{array}{l}5.848 \\
(9.08)^{* * *}\end{array}$ \\
\hline Pottery china earthenware & $\begin{array}{l}2.656 \\
(3.81)^{* * *}\end{array}$ & $\begin{array}{l}8.178 \\
(11.30)^{* * *}\end{array}$ \\
\hline Glass and products & $\begin{array}{l}3.270 \\
(4.60)^{* * *}\end{array}$ & $\begin{array}{l}5.986 \\
(8.67)^{* * *}\end{array}$ \\
\hline Other non-metallic mineral products & $\begin{array}{l}5.186 \\
(7.28)^{* * *}\end{array}$ & $\begin{array}{l}7.957 \\
(11.89)^{* * *}\end{array}$ \\
\hline Iron and steel & $\begin{array}{l}6.625 \\
(7.75)^{* * *}\end{array}$ & $\begin{array}{l}4.824 \\
(6.30)^{* * *}\end{array}$ \\
\hline Non-ferrous metals & $\begin{array}{l}5.448 \\
(5.91)^{* * *}\end{array}$ & $\begin{array}{l}5.791 \\
(6.92)^{* * *}\end{array}$ \\
\hline Fabricated metal products & $\begin{array}{l}5.106 \\
(6.96)^{* * *}\end{array}$ & $\begin{array}{l}5.082 \\
(7.56)^{* * *}\end{array}$ \\
\hline Machinery except electrical & $\begin{array}{l}4.143 \\
(5.16)^{* * *}\end{array}$ & $\begin{array}{l}3.224 \\
(4.47)^{* * *}\end{array}$ \\
\hline Machinery electric & $\begin{array}{l}4.684 \\
(6.60)^{* * *}\end{array}$ & $\begin{array}{l}4.237 \\
(6.58)^{* * *}\end{array}$ \\
\hline Transport equipment & $\begin{array}{l}6.368 \\
(8.13)^{* * *}\end{array}$ & $\begin{array}{l}5.058 \\
(7.22)^{* * *}\end{array}$ \\
\hline Professional and scientific equipment & $\begin{array}{l}4.490 \\
(4.75)^{* * *}\end{array}$ & $\begin{array}{l}5.383 \\
(6.22)^{* * *}\end{array}$ \\
\hline Other manufactured products & $\begin{array}{l}3.630 \\
(5.24)^{* * *}\end{array}$ & $\begin{array}{l}5.565 \\
(8.59) * * *\end{array}$ \\
\hline Observations & 19927 & 19927 \\
\hline Pseudo R-squared & 0.1340 & 0.2191 \\
\hline Time fixed effects included & yes & yes \\
\hline
\end{tabular}

Marginal effects are presented in the table. Absolute value of $\mathrm{z}$ statistics in parentheses, ${ }^{*}$ significant at $10 \%$; ${ }^{* *}$ significant at $5 \% ; * * *$ significant at $1 \%$ 
Table 4 Tobit estimation over time

\begin{tabular}{|c|c|c|c|c|}
\hline & Using average distance & Using harmonic distance & Using average distance & Using harmonic distance \\
\hline \multirow[t]{2}{*}{ GDPpartner } & 1.964 & 2.027 & 0.565 & 0.571 \\
\hline & $(3.36)^{* * *}$ & $(3.47)^{* * *}$ & $(9.34) * * *$ & $(9.48) * * *$ \\
\hline \multirow[t]{2}{*}{ GDPreporting } & 0.838 & 0.793 & 0.302 & 0.273 \\
\hline & $(1.11)$ & $(1.05)$ & $(3.65)^{* * *}$ & $(3.31)^{* * *}$ \\
\hline \multirow[t]{2}{*}{ GDPC } & -0.125 & -0.123 & -0.014 & -0.009 \\
\hline & $(4.80)^{* * *}$ & $(4.74)^{* * *}$ & $(2.42)^{* *}$ & $(1.54)$ \\
\hline \multirow[t]{2}{*}{ adjacency } & 0.293 & -0.020 & 0.555 & 0.280 \\
\hline & $(2.66)^{* * *}$ & $(0.18)$ & $(6.04)^{* * *}$ & $(2.97)^{* * *}$ \\
\hline \multirow[t]{2}{*}{ Europe Agreement } & 1.036 & 0.996 & 1.149 & 1.121 \\
\hline & $(10.79)^{* * *}$ & $(10.40)^{* * *}$ & $(14.81)^{* * *}$ & $(14.50)^{* * *}$ \\
\hline \multirow[t]{2}{*}{ CEFTA } & -0.418 & -0.581 & -0.368 & -0.519 \\
\hline & $(2.91)^{* * *}$ & $(4.05)^{* * *}$ & $(3.06)^{* * *}$ & $(4.32) * * *$ \\
\hline \multirow[t]{2}{*}{ FTA } & 0.018 & 0.076 & -0.046 & -0.000 \\
\hline & $(0.05)$ & $(0.19)$ & $(0.14)$ & $(0.00)$ \\
\hline \multirow[t]{2}{*}{ Distance } & -2.345 & -2.514 & -2.118 & -2.258 \\
\hline & $(28.72)^{* * *}$ & $(30.49)^{* * *}$ & $(31.19)^{* * *}$ & $(33.15)^{* * *}$ \\
\hline \multirow[t]{2}{*}{ Home OA 92} & 5.300 & 4.037 & 6.311 & 5.231 \\
\hline & $(4.79)^{* * *}$ & $(3.67)^{* * *}$ & $(6.98) * * *$ & $(5.79) * * *$ \\
\hline \multirow[t]{2}{*}{ Home OA 93} & 7.155 & 5.878 & 8.149 & 7.063 \\
\hline & $(6.42)^{* * *}$ & $(5.29) * * *$ & $(9.00)^{* * *}$ & $(7.81)^{* * *}$ \\
\hline \multirow[t]{2}{*}{ Home OA 94} & 7.487 & 6.105 & 8.160 & 6.980 \\
\hline & $(7.01)^{* * *}$ & $(5.72)^{* * *}$ & $(9.41)^{* * *}$ & $(8.04)^{* * *}$ \\
\hline \multirow[t]{2}{*}{ Home OA 95} & 7.621 & 6.224 & 8.273 & 7.082 \\
\hline & $(7.13)^{* * *}$ & $(5.83)^{* * *}$ & $(9.54)^{* * *}$ & $(8.16)^{* * *}$ \\
\hline \multirow[t]{2}{*}{ Home OA 96} & 6.234 & 4.840 & 6.837 & 5.645 \\
\hline & $(5.86)^{* * *}$ & $(4.57)^{* * *}$ & $(7.89)^{* * *}$ & $(6.52)^{* * *}$ \\
\hline \multirow[t]{2}{*}{ Home OA 97} & 6.099 & 4.789 & 7.564 & 6.450 \\
\hline & $(5.74)^{* * *}$ & $(4.52) * * *$ & $(8.71)^{* * *}$ & $(7.43)^{* * *}$ \\
\hline \multirow[t]{2}{*}{ Home OA 98} & 5.956 & 4.685 & 7.133 & 6.053 \\
\hline & $(4.86)^{* * *}$ & $(3.85)^{* * *}$ & $(7.14)^{* * *}$ & $(6.07) * * *$ \\
\hline \multirow[t]{2}{*}{ Home NA 92} & -0.359 & -0.412 & -0.258 & -0.306 \\
\hline & $(2.53)^{* *}$ & $(2.90) * * *$ & $(2.01)^{* *}$ & $(2.39)^{* *}$ \\
\hline \multirow[t]{2}{*}{ Home NA 93} & 5.693 & 4.406 & 6.243 & 5.193 \\
\hline & $(10.04) * * *$ & $(7.71)^{* * *}$ & $(13.64)^{* * *}$ & $(11.22)^{* * *}$ \\
\hline Home NA 94 & 5.682 & 4.242 & 6.453 & 5.290 \\
\hline & $(10.50)^{* * *}$ & $(7.74)^{* * *}$ & $(14.72)^{* * *}$ & $(11.88)^{* * *}$ \\
\hline Home NA 95 & 5.719 & 4.265 & 6.614 & 5.442 \\
\hline & $(10.56) * * *$ & $(7.78)^{* * *}$ & $(15.06)^{* * *}$ & $(12.20)^{* * *}$ \\
\hline Home NA 96 & 4.237 & 2.796 & 5.011 & 3.837 \\
\hline & $(7.76)^{* * *}$ & $(5.09) * * *$ & $(11.25)^{* * *}$ & $(8.50)^{* * *}$ \\
\hline Home NA 97 & 4.206 & 2.921 & 4.878 & 3.820 \\
\hline & $(7.20)^{* * *}$ & $(4.99) * * *$ & $(10.27)^{* * *}$ & $(7.97)^{* * *}$ \\
\hline Home NA 98 & 3.970 & 2.715 & 4.823 & 3.796 \\
\hline & $(6.16)^{* * *}$ & $(4.22)^{* * *}$ & $(9.20)^{* * *}$ & $(7.20)^{* * *}$ \\
\hline Home MA 92 & 4.469 & 3.183 & 5.054 & 3.929 \\
\hline & $(7.37)^{* * *}$ & $(5.24) * * *$ & $(10.21)^{* * *}$ & $(7.87)^{* * *}$ \\
\hline Home MA 93 & 6.359 & 5.055 & 6.911 & 5.778 \\
\hline & $(10.45)^{* * *}$ & $(8.25)^{* * *}$ & $(14.00)^{* * *}$ & $(11.58) * * *$ \\
\hline Home MA 94 & 6.266 & 4.753 & 6.919 & 5.629 \\
\hline & $(11.19) * * *$ & $(8.38)^{* * *}$ & $(15.21)^{* * *}$ & $(12.16)^{* * *}$ \\
\hline Home MA 95 & 6.503 & 5.012 & 7.223 & 5.954 \\
\hline & $(11.27)^{* * *}$ & $(8.59)^{* * *}$ & $(15.41)^{* * *}$ & $(12.51)^{* * *}$ \\
\hline Home MA 96 & 4.833 & 3.333 & 5.502 & 4.218 \\
\hline & $(8.54)^{* * *}$ & $(5.84)^{* * *}$ & $(11.90)^{* * *}$ & $(8.98)^{* * *}$ \\
\hline Home MA 97 & 4.651 & 3.345 & 5.308 & 4.170 \\
\hline & $(7.36)^{* * *}$ & $(5.28) * * *$ & $(10.28)^{* * *}$ & $(8.01)^{* * *}$ \\
\hline Home MA 98 & 4.632 & 3.364 & 5.434 & 4.329 \\
\hline & $(6.38)^{* * *}$ & $(4.64) * * *$ & $(9.18)^{* * *}$ & $(7.28)^{* * *}$ \\
\hline
\end{tabular}




\begin{tabular}{lllll}
\hline Constant & -26.857 & -26.123 & 6.265 & 7.635 \\
& $(1.64)$ & $(1.60)$ & $(3.32)^{* * *}$ & $(4.05)^{* * *}$ \\
\hline Observations & 19927 & 19927 & 19927 & 19927 \\
Pseudo R-squared & 0.1331 & 0.1337 & 0.2171 & 0.2177 \\
\hline country fixed effects & yes & yes & no & no \\
\hline industry by country fixed- & no & no & yes & yes
\end{tabular}

effects

Time fixed effects are included for all equations. Country fixed effects indicate that country specific dummies are included for both reporting and partner country. 'Industry by country fixed effects' indicate that origin and destination fixed-effects interacted with industry dummies are included; Absolute value of $\mathrm{z}$ statistics in parentheses, $*$ significant at $10 \%$; $* *$ significant at $5 \%$; *** significant at 1\%; OA stands for old approach products, NA for new approach and MA for mixed approach products. 
Table 5 OLS and CLAD results by products using harmonic measure for distance

\begin{tabular}{|c|c|c|c|c|}
\hline & & $\begin{array}{l}\text { OLS with country } \\
\text { specific fixed effects }\end{array}$ & $\begin{array}{l}\text { OLS with country-industry } \\
\text { specific fixed effects }\end{array}$ & $\begin{array}{l}\text { CLAD with } \\
\text { country specific } \\
\text { fixed effects }\end{array}$ \\
\hline Food products & $\mathrm{OA}$ & $\begin{array}{l}7.918 \\
(0.383)^{* * *}\end{array}$ & $\begin{array}{l}6.425 \\
(0.419)^{* * *}\end{array}$ & $\begin{array}{l}4.942 \\
(0.368)\end{array}$ \\
\hline Beverages & NA & $\begin{array}{l}6.727 \\
(0.354)^{* * *}\end{array}$ & $\begin{array}{l}8.118 \\
(0.380)^{* * *}\end{array}$ & $\begin{array}{l}4.018 \\
(0.278)\end{array}$ \\
\hline Tobacco & $\mathrm{OA}$ & $\begin{array}{l}6.079 \\
(0.382) * * *\end{array}$ & $\begin{array}{l}8.175 \\
(0.697) * * *\end{array}$ & $\begin{array}{l}3.196 \\
(0.294)\end{array}$ \\
\hline Textiles & NA & $\begin{array}{l}5.313 \\
(0.444)^{* * * *}\end{array}$ & $\begin{array}{l}4.008 \\
(0.503)^{* * *}\end{array}$ & $\begin{array}{l}2.565 \\
(0.308)\end{array}$ \\
\hline Wearing apparel except footwear & NA & $\begin{array}{l}3.621 \\
(0.424)^{* * *}\end{array}$ & $\begin{array}{l}4.080 \\
(0.642)^{* * *}\end{array}$ & $\begin{array}{l}3.136 \\
(1.302)\end{array}$ \\
\hline Leather products & NA & $\begin{array}{l}3.767 \\
(0.400)^{* * *}\end{array}$ & $\begin{array}{l}6.321 \\
(0.479) * * *\end{array}$ & $\begin{array}{l}1.130 \\
(0.477)\end{array}$ \\
\hline Footwear except rubber or plastic & NA & $\begin{array}{l}4.079 \\
(0.307)^{* * *}\end{array}$ & $\begin{array}{l}4.727 \\
(0.413)^{* * *}\end{array}$ & $\begin{array}{l}1.373 \\
(0.485)\end{array}$ \\
\hline Wood products except furniture & NA & $\begin{array}{l}5.571 \\
(0.357)^{* * *}\end{array}$ & $\begin{array}{l}7.487 \\
(0.506)^{* * *}\end{array}$ & $\begin{array}{l}3.084 \\
(0.545)\end{array}$ \\
\hline Furniture except metal & NA & $\begin{array}{l}5.138 \\
(0.330)^{* * *}\end{array}$ & $\begin{array}{l}6.669 \\
(0.408)^{* * *}\end{array}$ & $\begin{array}{l}2.566 \\
(0.397)\end{array}$ \\
\hline Paper and products & MA & $\begin{array}{l}5.386 \\
(0.417)^{* * *}\end{array}$ & $\begin{array}{l}6.043 \\
(0.559)^{* * *}\end{array}$ & $\begin{array}{l}2.478 \\
(0.372)\end{array}$ \\
\hline Printing and publishing & MA & $\begin{array}{l}5.842 \\
(0.412)^{* * *}\end{array}$ & $\begin{array}{l}7.038 \\
(0.400)^{* * *}\end{array}$ & $\begin{array}{l}3.160 \\
(0.274)\end{array}$ \\
\hline Industrial chemicals & MA & $\begin{array}{l}6.544 \\
(0.305)^{* * *}\end{array}$ & $\begin{array}{l}3.437 \\
(0.343)^{* * *}\end{array}$ & $\begin{array}{l}3.156 \\
(0.254)\end{array}$ \\
\hline Other chemicals & MA & $\begin{array}{l}6.353 \\
(0.404)^{* * *}\end{array}$ & $\begin{array}{l}5.794 \\
(0.406)^{* * *}\end{array}$ & $\begin{array}{l}3.464 \\
(0.255)\end{array}$ \\
\hline Petroleum refineries & $\mathrm{OA}$ & $\begin{array}{l}6.827 \\
(0.500)^{* * *}\end{array}$ & $\begin{array}{l}8.927 \\
(0.473)^{* * *}\end{array}$ & $\begin{array}{l}3.923 \\
(0.439)\end{array}$ \\
\hline Miscellaneous petroleum and coal products & MA & $\begin{array}{l}6.227 \\
(0.862)^{* * *}\end{array}$ & $\begin{array}{l}10.238 \\
(0.839)^{* * *}\end{array}$ & $\begin{array}{l}1.461 \\
(1.739)\end{array}$ \\
\hline Rubber products & NA & $\begin{array}{l}3.836 \\
(0.517)^{* * *}\end{array}$ & $\begin{array}{l}5.263 \\
(0.522)^{* * *}\end{array}$ & $\begin{array}{l}1.214 \\
(0.373)\end{array}$ \\
\hline Plastic products & MA & $\begin{array}{l}5.670 \\
(0.410)^{* * *}\end{array}$ & $\begin{array}{l}6.701 \\
(0.481)^{* * *}\end{array}$ & $\begin{array}{l}2.795 \\
(0.358)\end{array}$ \\
\hline Pottery china earthenware & NA & $\begin{array}{l}3.658 \\
(0.442)^{* * *}\end{array}$ & $\begin{array}{l}6.722 \\
(0.535)^{* * *}\end{array}$ & $\begin{array}{l}0.755 \\
(0.403)\end{array}$ \\
\hline Glass and products & MA & $\begin{array}{l}4.313 \\
(0.495)^{* * *}\end{array}$ & $\begin{array}{l}6.024 \\
(0.575)^{* * *}\end{array}$ & $\begin{array}{l}1.615 \\
(0.400)\end{array}$ \\
\hline Other non-metallic mineral products & MA & $\begin{array}{l}6.215 \\
(0.343)^{* * *}\end{array}$ & $\begin{array}{l}8.185 \\
(0.443)^{* * *}\end{array}$ & $\begin{array}{l}3.392 \\
(0.378)\end{array}$ \\
\hline Iron and steel & NA & $\begin{array}{l}7.528 \\
(0.301)^{* * *}\end{array}$ & $\begin{array}{l}6.054 \\
(0.403)^{* * *}\end{array}$ & $\begin{array}{l}3.613 \\
(0.466)\end{array}$ \\
\hline Non-ferrous metals & NA & $\begin{array}{l}6.343 \\
(0.263)^{* * *}\end{array}$ & $\begin{array}{l}6.586 \\
(0.412)^{* * *}\end{array}$ & $\begin{array}{l}2.772 \\
(0.369)\end{array}$ \\
\hline Fabricated metal products & NA & $\begin{array}{l}6.184 \\
(0.357)^{* * *}\end{array}$ & $\begin{array}{l}6.419 \\
(0.479) * * *\end{array}$ & $\begin{array}{l}3.321 \\
(0.419)\end{array}$ \\
\hline Machinery except electrical & NA & $\begin{array}{l}5.233 \\
(0.572)^{* * *}\end{array}$ & $\begin{array}{l}4.818 \\
(0.566)^{* * *}\end{array}$ & $\begin{array}{l}3.367 \\
(0.490)\end{array}$ \\
\hline Machinery electric & MA & $\begin{array}{l}5.725 \\
(0.525)^{* * *}\end{array}$ & $\begin{array}{l}5.526 \\
(0.542)^{* * *}\end{array}$ & $\begin{array}{l}3.130 \\
(0.466)\end{array}$ \\
\hline Transport equipment & MA & $\begin{array}{l}7.240 \\
(0.464)^{* * *}\end{array}$ & $\begin{array}{l}6.226 \\
(0.564)^{* * *}\end{array}$ & $\begin{array}{l}3.921 \\
(0.372)\end{array}$ \\
\hline Professional and scientific equipment & NA & $\begin{array}{l}5.372 \\
(0.527)^{* * *}\end{array}$ & $\begin{array}{l}6.127 \\
(0.544)^{* * *}\end{array}$ & $\begin{array}{l}1.248 \\
(1.151)\end{array}$ \\
\hline Other manufactured products & MA & $\begin{array}{l}4.651 \\
(0.405)^{* * *}\end{array}$ & $\begin{array}{l}6.187 \\
(0.434)^{* * *}\end{array}$ & $\begin{array}{l}2.240 \\
(0.613)\end{array}$ \\
\hline Observations & & 19927 & 19927 & 19927 \\
\hline R-squared & & 0.54 & 0.7 & 0.33 \\
\hline
\end{tabular}


Table 6 OLS and CLAD estimations over time (using harmonic distance measures)

\begin{tabular}{|c|c|c|c|}
\hline & $\begin{array}{l}\text { OLS with country specific } \\
\text { fixed effects }\end{array}$ & $\begin{array}{l}\text { OLS with country-industry } \\
\text { specific fixed effects }\end{array}$ & $\begin{array}{l}\text { CLAD with country specific } \\
\text { fixed effects }\end{array}$ \\
\hline GDPpartner & $\begin{array}{l}0.981 \\
(0.503)^{*}\end{array}$ & $\begin{array}{l}0.537 \\
(0.074) * * *\end{array}$ & $\begin{array}{l}3.527 \\
(1.137)\end{array}$ \\
\hline GDPreporting & $\begin{array}{l}2.502 \\
(0.651)^{* * *}\end{array}$ & $\begin{array}{l}0.405 \\
(0.088)^{* * *}\end{array}$ & $\begin{array}{l}4.412 \\
(0.846)\end{array}$ \\
\hline GDPC & $\begin{array}{l}-0.133 \\
(0.023)^{* * *}\end{array}$ & $\begin{array}{l}-0.014 \\
(0.007)^{* *}\end{array}$ & $\begin{array}{l}-0.161 \\
(0.027)\end{array}$ \\
\hline adjacency & $\begin{array}{l}0.296 \\
(0.091)^{* * *}\end{array}$ & $\begin{array}{l}0.526 \\
(0.083)^{* * *}\end{array}$ & $\begin{array}{l}-0.939 \\
(0.152)\end{array}$ \\
\hline Europe Agreement & $\begin{array}{l}0.901 \\
(0.087)^{* * *}\end{array}$ & $\begin{array}{l}0.938 \\
(0.070) * * *\end{array}$ & $\begin{array}{l}0.659 \\
(0.118)\end{array}$ \\
\hline CEFTA & $\begin{array}{l}-0.210 \\
(0.121)^{*}\end{array}$ & $\begin{array}{l}-0.127 \\
(0.095)\end{array}$ & $\begin{array}{l}-1.008 \\
(0.163)\end{array}$ \\
\hline FTA & $\begin{array}{l}-0.487 \\
(0.371)\end{array}$ & $\begin{array}{l}-0.525 \\
(0.296)^{*}\end{array}$ & $\begin{array}{l}0.815 \\
(0.480)\end{array}$ \\
\hline Distance & $\begin{array}{l}-1.991 \\
(0.070) * * *\end{array}$ & $\begin{array}{l}-1.693 \\
(0.066)^{* * *}\end{array}$ & $\begin{array}{l}-3.969 \\
(0.144)\end{array}$ \\
\hline Home OA 92 & $\begin{array}{l}5.255 \\
(0.758)^{* * *}\end{array}$ & $\begin{array}{l}5.927 \\
(0.901)^{* * *}\end{array}$ & $\begin{array}{l}2.980 \\
(0.867)\end{array}$ \\
\hline Home OA 93 & $\begin{array}{l}6.716 \\
(0.748)^{* * *}\end{array}$ & $\begin{array}{l}7.360 \\
(0.873)^{* * *}\end{array}$ & $\begin{array}{l}4.009 \\
(0.698)\end{array}$ \\
\hline Home OA 94 & $\begin{array}{l}6.854 \\
(0.644)^{* * *}\end{array}$ & $\begin{array}{l}7.295 \\
(0.794) * * *\end{array}$ & $\begin{array}{l}3.838 \\
(0.855)\end{array}$ \\
\hline Home OA 95 & $\begin{array}{l}6.930 \\
(0.634)^{* * *}\end{array}$ & $\begin{array}{l}7.349 \\
(0.769)^{* * *}\end{array}$ & $\begin{array}{l}4.133 \\
(0.498)\end{array}$ \\
\hline Home OA 96 & $\begin{array}{l}5.835 \\
(0.582)^{* * *}\end{array}$ & $\begin{array}{l}6.234 \\
(0.728)^{* * *}\end{array}$ & $\begin{array}{l}3.050 \\
(0.436)\end{array}$ \\
\hline Home OA 97 & $\begin{array}{l}5.749 \\
(0.551)^{* * *}\end{array}$ & $\begin{array}{l}6.726 \\
(0.768)^{* * *}\end{array}$ & $\begin{array}{l}3.042 \\
(0.440)\end{array}$ \\
\hline Home OA 98 & $\begin{array}{l}5.726 \\
(0.696)^{* * *}\end{array}$ & $\begin{array}{l}6.419 \\
(0.880)^{* * *}\end{array}$ & $\begin{array}{l}2.837 \\
(0.689)\end{array}$ \\
\hline Home NA 92 & $\begin{array}{l}-0.361 \\
(0.134)^{* * *}\end{array}$ & $\begin{array}{l}-0.230 \\
(0.127)^{*}\end{array}$ & $\begin{array}{l}-0.689 \\
(0.145)\end{array}$ \\
\hline Home NA 93 & $\begin{array}{l}5.229 \\
(0.383)^{* * *}\end{array}$ & $\begin{array}{l}5.775 \\
(0.372)^{* * *}\end{array}$ & $\begin{array}{l}2.645 \\
(0.375)\end{array}$ \\
\hline Home NA 94 & $\begin{array}{l}4.965 \\
(0.364)^{* * *}\end{array}$ & $\begin{array}{l}5.630 \\
(0.359)^{* * *}\end{array}$ & $\begin{array}{l}2.343 \\
(0.453)\end{array}$ \\
\hline Home NA 95 & $\begin{array}{l}4.946 \\
(0.366)^{* * *}\end{array}$ & $\begin{array}{l}5.676 \\
(0.336)^{* * *}\end{array}$ & $\begin{array}{l}2.203 \\
(0.304)\end{array}$ \\
\hline Home NA 96 & $\begin{array}{l}3.759 \\
(0.338)^{* * *}\end{array}$ & $\begin{array}{l}4.450 \\
(0.328)^{* * *}\end{array}$ & $\begin{array}{l}1.248 \\
(0.495)\end{array}$ \\
\hline Home NA 97 & $\begin{array}{l}3.879 \\
(0.357)^{* * *}\end{array}$ & $\begin{array}{l}4.555 \\
(0.353)^{* * *}\end{array}$ & $\begin{array}{l}1.512 \\
(0.552)\end{array}$ \\
\hline Home NA 97 & $\begin{array}{l}3.757 \\
(0.419)^{* * *}\end{array}$ & $\begin{array}{l}4.482 \\
(0.395)^{* * *}\end{array}$ & $\begin{array}{l}1.469 \\
(0.510)\end{array}$ \\
\hline Home MA 92 & $\begin{array}{l}4.368 \\
(0.425)^{* * *}\end{array}$ & $\begin{array}{l}5.013 \\
(0.434)^{* * *}\end{array}$ & $\begin{array}{l}1.670 \\
(0.524)\end{array}$ \\
\hline Home MA 93 & $\begin{array}{l}5.868 \\
(0.428)^{* * *}\end{array}$ & $\begin{array}{l}6.464 \\
(0.428)^{* * *}\end{array}$ & $\begin{array}{l}2.884 \\
(0.537)\end{array}$ \\
\hline Home MA 94 & $\begin{array}{l}5.436 \\
(0.384)^{* * *}\end{array}$ & $\begin{array}{l}6.151 \\
(0.388)^{* * *}\end{array}$ & $\begin{array}{l}2.540 \\
(0.429)\end{array}$ \\
\hline Home MA 95 & $\begin{array}{l}5.679 \\
(0.372)^{* * *}\end{array}$ & $\begin{array}{l}6.442 \\
(0.375)^{* * *}\end{array}$ & $\begin{array}{l}2.667 \\
(0.361)\end{array}$ \\
\hline Home MA 96 & $\begin{array}{l}4.274 \\
(0.366)^{* * *}\end{array}$ & $\begin{array}{l}5.026 \\
(0.380)^{* * *}\end{array}$ & $\begin{array}{l}1.573 \\
(0.325)\end{array}$ \\
\hline Home MA 97 & $\begin{array}{l}4.287 \\
(0.390)^{* * *}\end{array}$ & $\begin{array}{l}5.000 \\
(0.352)^{* * *}\end{array}$ & $\begin{array}{l}1.707 \\
(0.541)\end{array}$ \\
\hline Home MA 98 & $\begin{array}{l}4.406 \\
(0.461)^{* * *}\end{array}$ & $\begin{array}{l}5.154 \\
(0.378)^{* * *}\end{array}$ & $\begin{array}{l}1.866 \\
(0.350)\end{array}$ \\
\hline Constant & $\begin{array}{l}-36.358 \\
(14.223)^{* *}\end{array}$ & $\begin{array}{l}2.466 \\
(2.038)\end{array}$ & $\begin{array}{l}-100.310 \\
(26.218)\end{array}$ \\
\hline Observations & 19927 & 19927 & $17207^{1}$ \\
\hline R-squared & 0.53 & 0.70 & $0.35^{2}$ \\
\hline
\end{tabular}


Time fixed effects are included for all equations. Country fixed effects indicate that country specific dummies are included for both reporting and partner country. 'Industry by country fixed effects' indicate that origin and destination fixed-effects interacted with industry dummies are included; Robust standard errors in parentheses for OLS, and standard errors for CLAD estimations, * significant at $10 \%$; $* *$ significant at $5 \% ; * * *$ significant at $1 \%{ }^{1}$ final sample size ${ }^{2}$ pseudo-R2 


\section{Appendix I. Tables}

\section{Table 7 International and internal weighted distances for Bulgaria, Czech Republic, Hungary, Latvia, Poland, Cyprus}

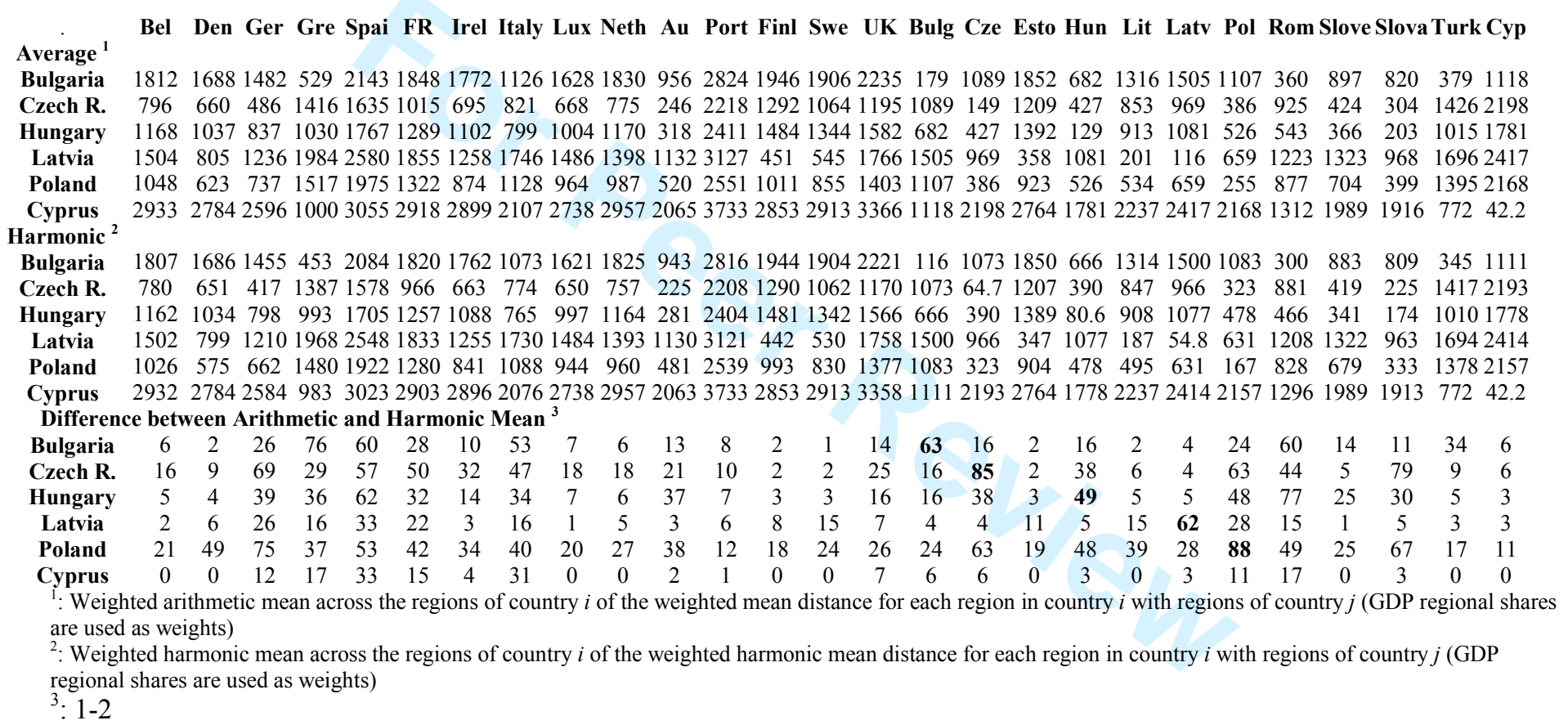


Table 8 List of industries included in the analysis

\begin{tabular}{|c|c|c|}
\hline ISIC code & product category & Approach applied \\
\hline 311 & Food products & Old approach \\
\hline 313 & Beverages & New approach \\
\hline 314 & Tobacco & Old approach \\
\hline 321 & Textiles & New approach \\
\hline 322 & Wearing apparel except footwear & New approach \\
\hline 323 & Leather products & New approach \\
\hline 324 & Footwear except rubber or plastic & New approach \\
\hline 331 & Wood products except furniture & New approach \\
\hline 332 & Furniture except metal & New approach \\
\hline 341 & Paper and products & Mixed approach \\
\hline 342 & Printing and publishing & Mixed approach \\
\hline 351 & Industrial chemicals & Mixed approach \\
\hline 352 & Other chemicals & Mixed approach \\
\hline 353 & Petroleum refineries & Old approach \\
\hline 354 & Miscellaneous petroleum and coal products & Mixed approach \\
\hline 355 & Rubber products & New approach \\
\hline 356 & Plastic products & Mixed approach \\
\hline 361 & Pottery china earthenware & New approach \\
\hline 362 & Glass and products & Mixed approach \\
\hline 369 & Other non-metallic mineral products & Mixed approach \\
\hline 371 & Iron and steel & New approach \\
\hline 372 & Non-ferrous metals & New approach \\
\hline 381 & Fabricated metal products & New approach \\
\hline 382 & Machinery except electrical & New approach \\
\hline 383 & Machinery electric & Mixed approach \\
\hline 384 & Transport equipment & Mixed approach \\
\hline 385 & Professional and scientific equipment & New approach \\
\hline 390 & Other manufactured products & Mixed approach \\
\hline
\end{tabular}




\section{Appendix II Distance measurement}

We have used information at the regional level so as to construct a weighted measure of distance both for between-countries and internal distances. In formula (1) we have used regional GDP shares as weights. The use of a weighted measure has the main advantage of an integrated methodology for calculating both international and intra-national distances. Relying on Head and Mayer (2000 and 2001) we have extended the calculation of average and effective distances (international and internal) to 6 reporting CEECs countries (Cyprus, Bulgaria, Czech Republic, Hungary, Latvia and Poland). Both arithmetic and harmonic means have been calculated in order to check for differences in results from using an aggregation formula coherent with evidence on the distance variable from previous gravity exercises.

Distances have been calculated by applying the great circle formula to latitude and longitude data of the main city of each region. The main city is the most populated city which most of the time coincides with the administrative capital of the region (data on population have been recovered from www.citiesandagglomerations.com ). Data on the weight of each region have been collected from the REGIO database, which provides GDP data for NUTS regions in the EU, and since 1992 in the accession countries as well. The weights used refer to 1996, since the dynamics of the spatial distribution of economic activities does not significantly vary from year to year. The internal distances within each region have been calculated by using Head and Mayer's $(2000)$ area based formula $(.67 * \sqrt{\text { area } / \pi})$ which assumes that production in sub-national regions is concentrated in a single point at the centre of a disk and consumers are uniformly distributed across the disk.

International distances have been calculated with respect to all $15 \mathrm{EU}$ countries (Belgium and Luxemburg have been merged) and the other trade partners in the region (Czech Republic, Estonia, Lithuania, Slovenia, Slovakia, Romania, Turkey). Regional detailed data on latitude and longitude and economic weight for partners' regions have been used in order to construct a weighted measure. NUTS1 level of disaggregation has been considered ${ }^{18}$.

International and internal distance calculations are presented in Table 1. As shown in the last rows the arithmetic mean is always bigger than the harmonic one. There is a potential for

\footnotetext{
${ }^{18}$ Finland and Sweden have been considered as a country concentrated in one region whose main cities are Helsinki and Stockholm. Data on GDP provide sufficient evidence main activities are concentrated in that region. NUTS2 regions have been used for Portugal and Ireland.

Also Cyprus has been considered as one region which includes only the Greek part, since data on the Turkish part of the island were not found.
} 
having illusory border effects since for each country (except Cyprus) the difference is bigger for the internal measure (in bold character) than for the international distances. This means that border effects are likely to arise because the overestimation of internal distances will fail to explain the higher internal trade. What could look like a border effect risks being simply an unaccounted for distance effect. Therefore results obtained with both means will be compared. $^{19}$

\footnotetext{
${ }^{19}$ Cyprus has been considered as one region, since the lack of geographical disaggregated data. Therefore Helliwell and Verdier $(2001)$ area based formula $(.52 * \sqrt{\text { area }})$ has been used for calculating its internal distance and does not vary between the arithmetic and the harmonic mean. The choice of this particular formula has been motivated by the particular shape of Cyprus.
} 
